\title{
Global Exploration and Production Capacity for Platinum-Group Metals From 1995 Through 2015
}

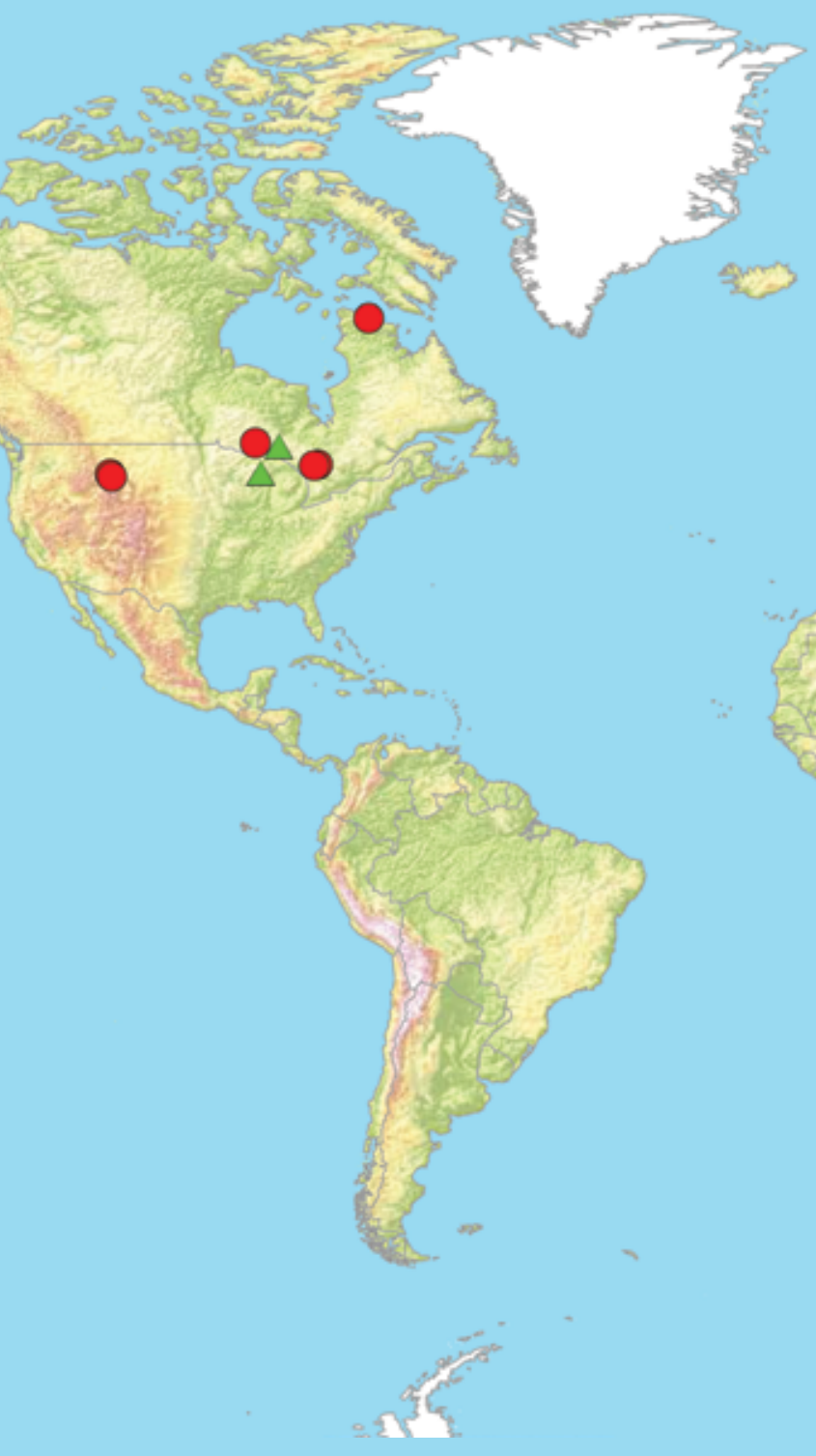

Scientific Investigations Report 2012-5164 Version 1.1 
Cover. Map of the world showing the locations where platinum-group metals were produced in 2010 (red circles), where facilities were being developed (yellow squares), and where sites were at such an advanced stage of exploration that the deposit was likely to begin production by 2015 (green triangles). Base derived from Global Multiresolution Terrain Elevation Data 2010 and data are from Johnson Matthey plc (2010) and Butler (2011, p. 16-23). 


\section{Global Exploration and Production Capacity for Platinum-Group Metals From 1995 Through 2015}

By David R. Wilburn

Scientific Investigations Report 2012-5164 Version 1.1 


\title{
U.S. Department of the Interior \\ KEN SALAZAR, Secretary \\ U.S. Geological Survey \\ Marcia K. McNutt, Director
}

\author{
U.S. Geological Survey, Reston, Virginia: 2012 \\ Revised and republished December 2012
}

\begin{abstract}
For more information on the USGS - the Federal source for science about the Earth, its natural and living resources, natural hazards, and the environment, visit http://www.usgs.gov or call 1-888-ASK-USGS.

For an overview of USGS information products, including maps, imagery, and publications, visit http://www.usgs.gov/pubprod

To order this and other USGS information products, visit http://store.usgs.gov
\end{abstract}

Any use of trade, firm, or product names is for descriptive purposes only and does not imply endorsement by the U.S. Government.

Although this information product, for the most part, is in the public domain, it also may contain copyrighted materials as noted in the text. Permission to reproduce copyrighted items must be secured from the copyright owner.

Suggested citation:

Wilburn, D.R., 2012, Global exploration and production capacity for platinum-group metals from 1995 through 2015 (version 1.1): U.S. Geological Survey Scientific Investigations Report 2012-5164, 26 p., at http://pubs.usgs.gov/ sir/2012/5164/. 


\section{Contents}

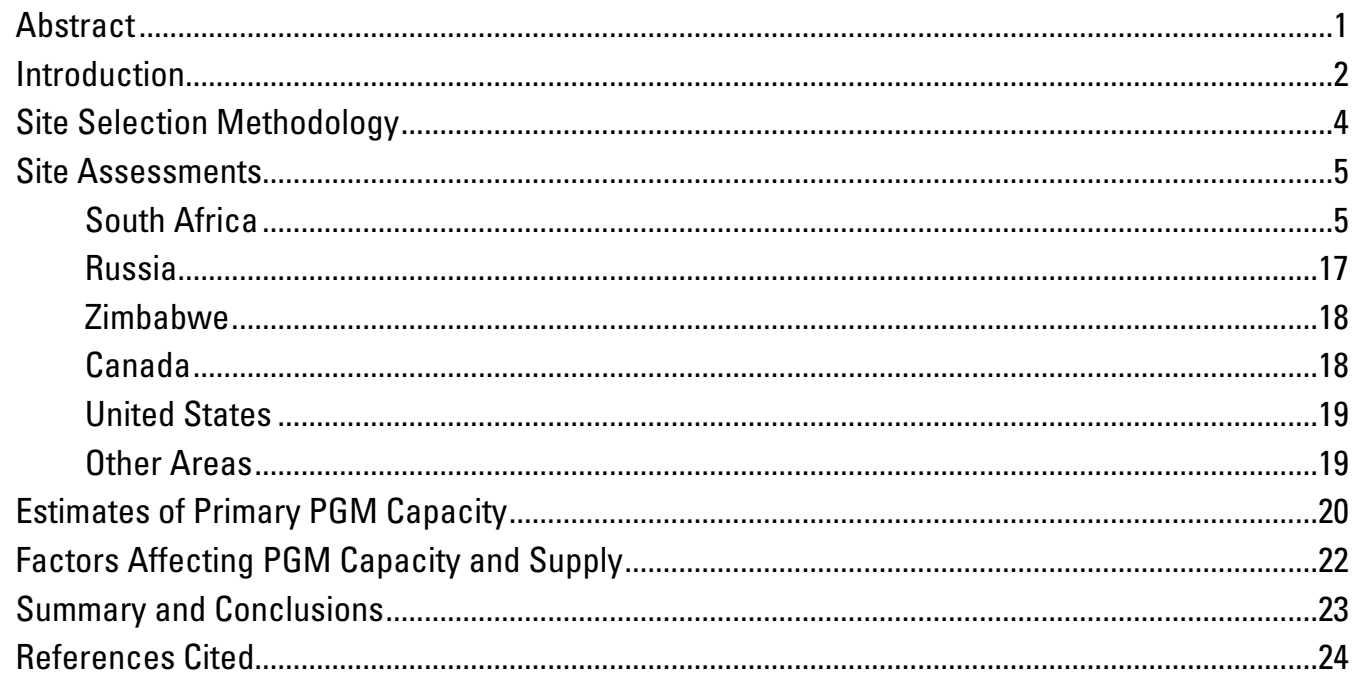

\section{Figures}

1. Map showing locations where platinum-group metals were produced in 2010 , where facilities were being developed, and where sites were at such an advanced stage of exploration that the deposit was likely to begin production of PGMs by 2015.

2. Chart showing worldwide production from countries producing significant refined platinum from 1995 through 2010

3. Chart showing production capacity of platinum and a timeline of significant events related to changes in platinum capacity in South Africa.

4. Chart showing estimated global production capacity for platinum from 1995 through 2015

5. Chart showing estimated global production capacity for palladium from 1995 through 2015

6. Chart showing average annual nominal prices of selected metals from 1995 through 2010

\section{Tables}

1. Operations included for analysis in this report.................................................................

2. Operations not included for statistical analysis in this report but that may become

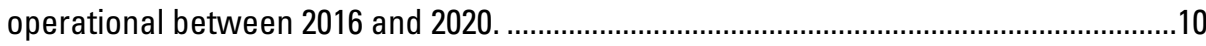

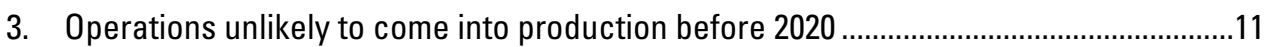

4. Selected South African platinum-group metal operations and projects ..........................12 


\title{
Conversion Factors
}

\begin{tabular}{lcl}
\hline Multiply & By & To obtain \\
\hline meter $(\mathrm{m})$ & Length & \\
kilometer $(\mathrm{km})$ & 3.281 & foot $(\mathrm{ft})$ \\
& 0.6214 & mile $(\mathrm{mi})$ \\
\hline kilogram $(\mathrm{kg})$ & Mass & \\
ton, metric $(\mathrm{t})$ & 2.205 & pound avoirdupois $(\mathrm{lb})$ \\
\hline
\end{tabular}

\section{Abbreviations}

\author{
BEE Black Economic Empowerment \\ NLEV National Low Emission Vehicle Program \\ NOx nitrogen oxides \\ PGM platinum-group metals \\ UG2 Upper Group Reef seam 2 \\ USGS U.S. Geological Survey
}




\title{
Global Exploration and Production Capacity for Platinum-Group Metals From 1995 Through 2015
}

\author{
By David R. Wilburn
}

\section{Abstract}

Platinum-group metals (PGMs) are required in a variety of commercial, industrial, and military applications for many existing and emerging technologies, yet the United States is highly dependent on foreign sources of PGMs. Information on global exploration for PGMs since 1995 has been used in this study as a basis for identifying locations where the industry has determined that exploration has provided data sufficient to warrant development of a new mine or expansion of an existing operation or where a significant increase in capacity for PGMs is anticipated by 2015. Discussions include an overview of the industry and the selected sites, factors affecting mineral supply, and circumstances leading to the development of mineral properties with the potential to affect mineral supply. Of the 52 sites or regional operations that were considered in this analysis, 16 sites were producing before 1995, 28 sites commenced production from 1995 through 2010, and 8 sites were expected to begin production from 2011 through 2015 if development plans came to fruition.

The United States imports PGMs primarily from Canada, Russia, South Africa, and Zimbabwe to meet increasing demand for these materials in a variety of specialized and high-tech applications. Feed sources of PGMs are changing in South Africa and Russia, which together accounted for about 89 percent of platinum production and 82 percent of palladium production in 2009. A greater amount of South African PGM capacity is likely to come from deeper, higher cost Upper Group Reef seam 2 deposits and deposits in the Eastern Bushveld area. Future Russian PGM capacity is likely to come from ore zones with generally lower PGM content and different platinum-to-palladium ratios than the nickel-rich ore that dominated PGM supply in the 1990s. Because PGM supply from Canada and Russia is derived as a byproduct of copper and nickel mining, the PGM supply from these countries is influenced by economic, environmental, political, and technological factors affecting exploration for and development of copper and nickel, as well as factors affecting the PGM industry. The recovery of PGMs from mill tailings since 2004 and the recycling of PGMs from catalytic converters, electrical components, and jewelry has increased since 1995 so that recycled PGMs recovered from these products accounted for about 30 percent of the supply of platinum worldwide and 29 percent of the supply of palladium worldwide in 2010.

Economic and geopolitical conditions have influenced PGM supply and demand. The global recession of 2008 and 2009 temporarily decreased demand for PGMs and constrained PGM mine exploration and development, at least through 2010. Legislation regulating the structure of the mining sector has affected mining in Russia, South Africa, and Zimbabwe. Stricter vehicle emissions standards in established markets since the 1980s have led to mandatory use of pollution control devices, such as catalytic converters, that contain PGMs and are required on vehicles in expanding markets, such as China and India.

It is expected that South Africa, Russia, Canada, and Zimbabwe will continue to be the principal sources of PGM at least for the next decade. Based on this review of the PGM industry, the world's platinum capacity, expressed in terms of recoverable platinum metal, increased from 1995 through 2010 by 77,000 kilograms $(\mathrm{kg})$ in South Africa, 9,000 kg in Zimbabwe, 6,000 kg in Russia, 2,000 kg in Botswana, and $2,000 \mathrm{~kg}$ in Canada. For the same period, palladium capacity worldwide increased by 44,000 kg in South Africa, 22,000 kg in Russia, 8,000 kg in Canada, 8,000 kg in the United States, $7,000 \mathrm{~kg}$ in Zimbabwe, and 3,000 kg in Botswana. Platinum capacity worldwide is expected to further increase by $24,000 \mathrm{~kg}$ in South Africa, 9,000 kg in Russia, 3,000 kg in Canada, and 2,000 kg in Zimbabwe from 2011 through 2015. Palladium capacity worldwide is likewise expected to increase an additional $16,000 \mathrm{~kg}$ in Russia, 14,000 kg in South Africa, $4,000 \mathrm{~kg}$ in Zimbabwe, and 1,000 kg in Canada if new or expanded mine and associated processing capacity comes into production as planned. It is likely that the magnitude of these changes in PGM capacity has been influenced by such factors as the global economy, electrical capacity shortages and mine safety concerns in South Africa, and geopolitical conditions in the major PGM producing countries. 


\section{Introduction}

An adequate and dependable supply of minerals is essential to meet the Nation's mineral demand. The U.S. Geological Survey (USGS) actively monitors global nonfuel mineral exploration, development, production, and consumption activities to better anticipate the location and quantity of future minerals supply. Data collected have been used to identify the locations (fig. 1) where recent exploration since 1995 has supported the development of new or expanded capacity for platinum group metals (PGMs).

PGMs, which include iridium, osmium, palladium, platinum, rhodium, and ruthenium, are required in a variety of commercial, industrial, and military applications for a variety of existing and emerging technologies. In 2010, the United States imported about 94 percent of the platinum and 58 percent of the palladium it consumed. PGMs are used primarily in the automobile sector as catalysts for air-pollution abatement in light- and heavy-duty vehicles, in fuel cells, and in petroleum refining; in the chemical sector as a catalyst in nitric acid production; in the electronics sector in computer hard discs, multilayer ceramic capacitors, and integrated circuits; in the glass manufacturing sector in the production of fiberglass, liquid crystal displays, and flat-panel displays; and in other applications, such as jewelry, medical and dental appliances, and as an investment.

The National Research Council (United States) identified the critical minerals and materials it determined were essential for industry and emerging technologies in the domestic economy and has concluded that the PGMs palladium, platinum, and rhodium should be considered critical because of limited availability and their potential for supply disruption (National Research Council, 2008, p. 137-147). A 2010 study prepared by the European Commission for the European Union also included PGMs in its list of 14 critical raw materials (European Commission, 2010, p. 6).

The leading use of palladium, platinum, and rhodium is as a component in automobile catalysts. The U.S. Environmental Protection Agency's National Low Emission Vehicle (NLEV) Program, which was implemented in 1997 as a voluntary program and Federally mandated by 2001, placed an emphasis on lowering hydrocarbon emissions in automobiles and lightduty trucks and required the use of catalytic converters in most vehicles to lower vehicle emissions. This regulation favored increased use of palladium over platinum in catalytic converters for gasoline-powered vehicles. Similar regulation restricted nitrogen oxides (NOx) emissions from vehicles, resulting in increased use of rhodium in catalytic converters for vehicles with gasoline engines and of platinum and rhodium in catalytic converters designed for diesel engines. Although palladium, platinum, and rhodium are all used in the automotive sector in catalytic converters, their individual application and suitability varies sufficiently so that only certain substitutions can occur. Palladium may be partially substituted for platinum in catalytic converters for most gasoline-fueled vehicles, but palladium may not be universally substituted for platinum in converters designed for diesel engines, and there is presently no less expensive substitute for rhodium to control NOx emissions (National Research Council, 2008, p. 137-147). Any interruption in the supply of catalytic converters because of a PGM supply deficit may increase the cost of automobiles and limit production of vehicles that use PGM-rich catalytic converters because internal combustion gasoline- and diesel-fueled vehicles cannot be sold in the United States without catalytic converters. Similarly, a deficit in PGM supply could affect the cost of materials, products, and fuels used by many other downstream end-use industries. A sustained PGM supply deficit could reprioritize or delay the development and implementation of technologies that may reduce fossil fuel consumption, increase energy efficiency, and improve air quality for such technologies that require PGMs; alternatively, a sustained PGM supply deficit could stimulate the development of new technologies that use no or small amounts of PGMs.

Although deposits containing PGMs are widespread, those mined for PGMs because the PGMs are economically recoverable at 2010 prices are limited. The relative abundance of PGMs in the Earth's crust is orders of magnitude lower than the relative abundances of the base metals with which they are often associated. In order of importance relative to world supply, South Africa, Russia, Canada, Zimbabwe, and the United States are the leading sources of PGM mining. In 2010, South Africa accounted for about 78 percent of global primary production of other PGMs (iridium, osmium, rhodium, and ruthenium), 77 percent of global primary production of platinum, and 41 percent of global primary production of palladium in 2009 (Loferski, 2012a, p. 57.12). In 2010, Russia accounted for about 42 percent of global primary production of palladium, 13 percent of global primary production of platinum, and 16 percent of global primary production of other PGMs (Loferski, 2012, p. 57.12). Data compiled from public sources as of April 2011 suggest that about 82 percent of the global PGM reserves reported by company sources at the proven or probable level are located in South Africa, and 7 percent of the reserves are located in Russia (Metals Economics Group, 2010). Additional PGM reserves are located in Zimbabwe (6 percent), the United States ( 2 percent), Canada (1.5 percent), and China (1.5 percent). Negligible reserve amounts are reported in other areas. It should be noted that different companies use varying criteria to determine site reserve estimates. Because most of the exploration for PGMs is occurring near producing areas or as extensions of known occurrences, PGM reserves in other areas are viewed as negligible, although sizeable PGM resources have been identified in Australia and Finland, where there is no active production and initiating production could require a substantial initial outlay of capital.

The following are the principal geologic environments associated with PGM-bearing deposits from which large-scale production has taken place (Vermaak, 1995; Wilburn and Bleiwas, 2005, p. 11):

- stratiform deposits found in large Precambrian mafic to ultramafic layered intrusions; examples include the Merensky Reef and the Upper Group Reef seam 2 (UG2) of the Bushveld Complex in South Africa, the 


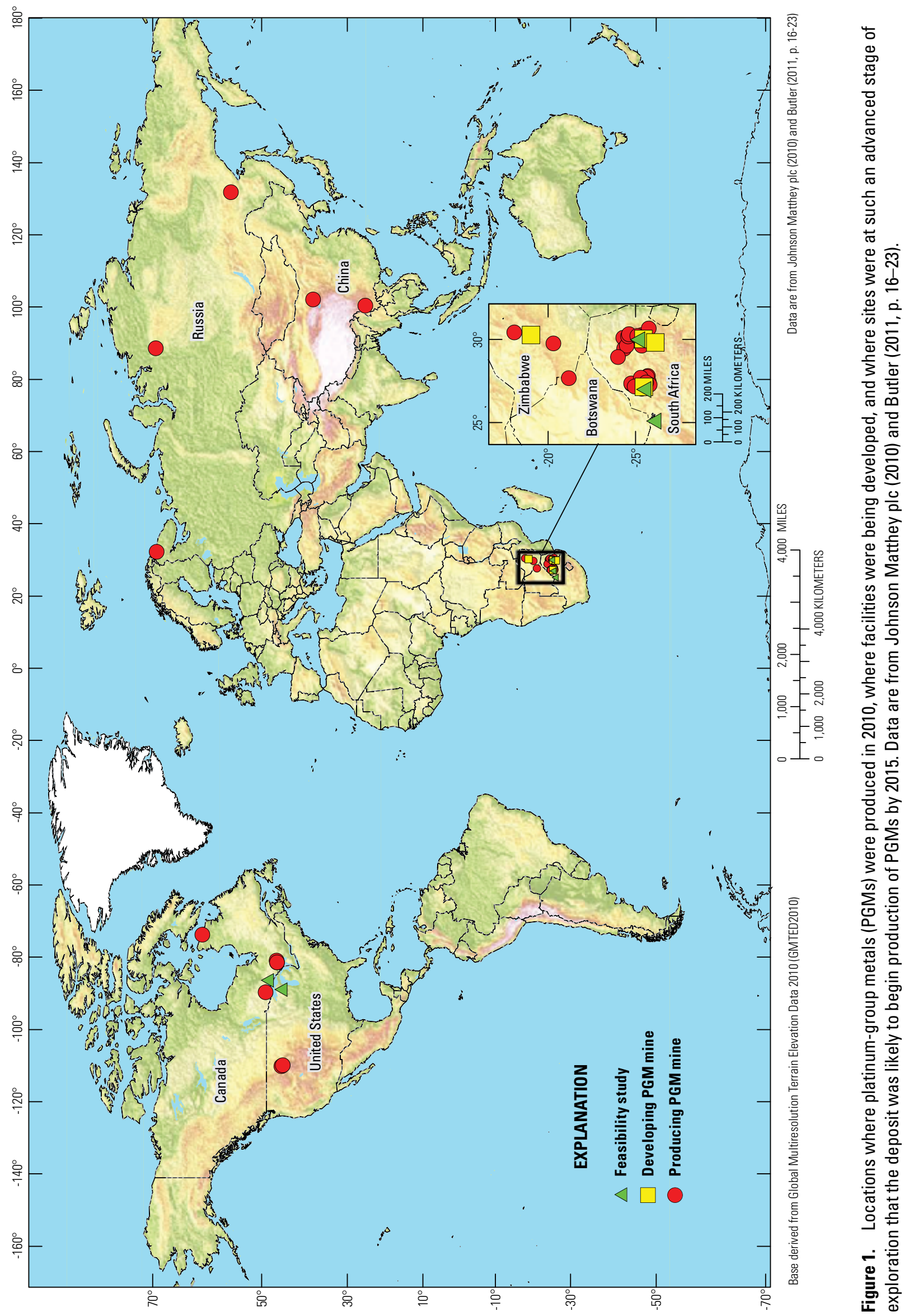


Great Dyke in Zimbabwe, and the Stillwater Complex in the United States;

- nickel- and copper-bearing gabbro-dolerite sills, such as those found in the Noril'sk-Talnakh District in Russia;

- norite intrusions with nickel and copper mineralization, such as the Sudbury irruptive complex in Canada; and

- disseminated sulfides enriched in PGMs associated with contact zones of mafic to ultramafic intrusions at the Platreef deposit in South Africa or composite plutons, such as the Lac des Iles deposit in Canada.

Large stratiform PGM deposits, such as the Bushveld and Stillwater Complexes, typically contain PGMs of sufficient grade and tonnage to be considered the primary products. PGMs are recovered as byproducts from Canadian and Russian nickel and copper deposits. PGMs also are recovered from alluvial and placer deposits containing platinum and gold in Columbia and Russia. The amounts and principal locations from which PGMs have been mined as a primary product and (or) recovered as a byproduct of base-metal mining from 1995 through 2010 are shown in figure 2 .

\section{Site Selection Methodology}

This report focuses on 52 projects or operations where mineral exploration has led to the development of a mine or the significant expansion of a mine and supporting facilities before 2011 and projects planned for development from 2011 through 2015 based on company plans reported as of April 2011.

Individual sites may include more than one mine if the operator considers the site as a single integrated operation and treats ore from these mines as a single feed source for processing. Projects were selected if they met at least one of the following criteria:

- initial production commenced after 1994;

- the mine or project had an actual or planned capacity greater than 4,500 kilograms per year $(\mathrm{kg} / \mathrm{yr})$ of an individual platinum-group element;

- the mine or project had a capacity greater than $10,000 \mathrm{~kg} / \mathrm{yr}$ of total recoverable PGMs or;

- PGMs are recovered as a byproduct of an operation with a capacity exceeding 40,000 metric tons per year ( $\mathrm{t} / \mathrm{yr})$ of contained copper or $15,000 \mathrm{t} / \mathrm{yr}$ of contained nickel in ore or recoverable product.

The assigned capacity cutoff of $4,500 \mathrm{~kg} / \mathrm{yr}$ represented about 2 percent of the average global production of platinum or 3 percent of the average global production of palladium from 1995 through 2009.

Table 1A lists the 45 sites that met the selection criteria, of which 15 sites were producing before 1995, 28 sites commenced production between 1995 and 2010, and 2 sites were expected to begin production between 2011 and 2015 . Table 1B lists 7 additional sites considered for analysis even

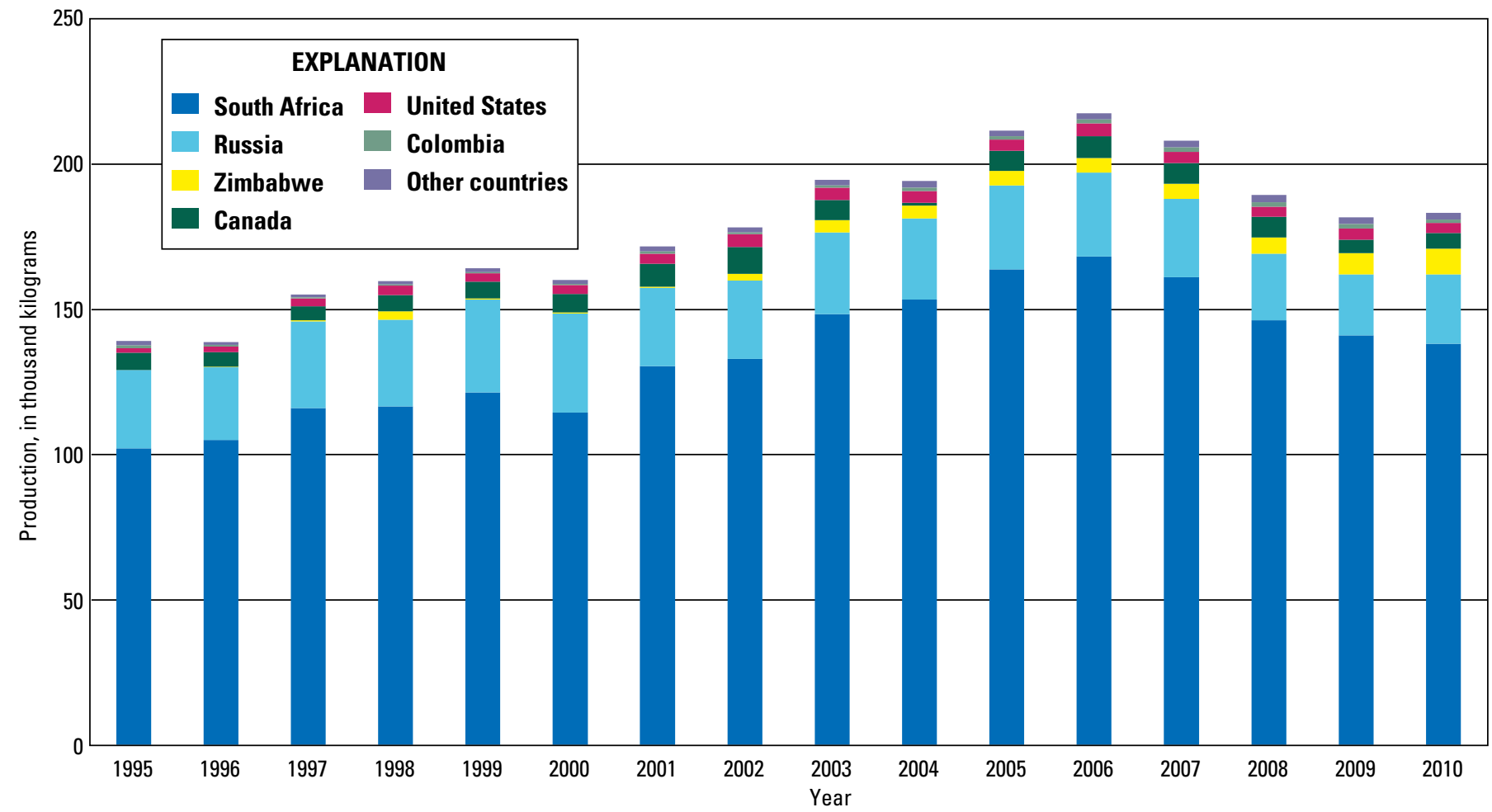

Figure 2. Worldwide production from countries producing significant refined platinum from 1995 through 2010. Production is measured in kilograms of platinum recovered. Refined production for the purposes of this chart is from primary sources only. Data are from Reese (1997), Hilliard (1998-2011), George (2006-2010), and Loferski (2009-2011, 2011a, b). 
though the selection criteria were not met, including 1 site that has produced intermittently and 6 additional sites that were expected to commence production between 2011 and 2015 but did not meet study capacity requirements; site capacity estimates are listed broken out for selected platinum-group metals and other commodities as of 2015. The map in figure 1 shows the locations where PGMs were produced in 2010, where facilities were being developed, and where sites were at such an advanced stage of exploration that the deposit was likely to begin production of PGMs by 2015 .

Table 1 also reports the estimated average platinum capacity utilization rate of each site. For the purposes of this report, the capacity utilization rate reflects the ratio of the average production of the principal PGMs from 2007 through 2010 compared with the estimated PGM capacity in 2010. The average capacity utilization rate for the 45 sites shown in table 1 was estimated to be 73 percent. This low value seems reasonable given that a number of operations had reduced production during 2008 and 2009 because of reduced demand for PGMs in the high-technology and automotive sectors resulting from the global recession. In addition, a number of operations had recently begun production and had not yet achieved full capacity.

In addition, 34 sites were evaluated, and selected information on these sites is reported in tables 2 and 3 . These sites either did not satisfy the capacity requirements specified in this study or would not achieve initial production until after 2015. Table 2 lists nine sites not included for analysis but which were most likely to come into production from 2016 to 2020 . Table 3 lists 25 additional sites evaluated in this study but not included for analysis because information as of April 2011 suggested that the site was either unlikely to come into production by 2020 or not sufficiently advanced in the exploration process to have developed an estimate of the site's expected capacity or the reported PGM capacity at the site was below the study cutoff level. The reasons why each site was excluded from statistical analysis are listed in tables 2 and 3. Sites where development decisions were made after April 2011 were not considered for this study.

Increasing prices and strong demand for PGMs during the past decade stimulated PGM exploration before the downturn in the global economy in mid-2008. In response to the economic recession and subsequent drop in PGM prices late in 2008 and early in 2009, many companies reduced exploration spending, delayed development, and reduced or curtailed production until economic conditions improved and demand for PGMs strengthened. Table 3 notes those sites where development had been delayed beyond 2020 and briefly describes the development status of each operation as reported at the beginning of 2011. During 2012, labor unrest in South Africa resulted in companies reviewing future capacity and development plans for some of the South African PGM mines and projects. Consequently, development plans reported in this report may have changed based on events that have taken place after the report was written.

\section{Site Assessments}

\section{South Africa}

The Bushveld Complex in South Africa was discovered in 1906 and was first mined as a placer. Because of its favorable economics, immense size, and PGM-rich mineralogy, as determined by subsequent exploration, the Bushveld Complex has become the leading source of PGMs in the world since the 1920s. The USGS estimated that about 77 percent of the platinum production and 41 percent of palladium production in 2010 came from South Africa (Loferski, 2012, p. 57.12). The Bushveld Complex has been subdivided into three areas, the Northern limb (hosting the Platreef) and the Eastern and Western limbs (each hosting the Merensky Reef and UG2 seam). The Merensky Reef has been a principal source of PGMs since it was first worked in 1925 because of its shallower depth and generally higher PGM content than the UG2; in addition, the Merensky Reef has a lower chromite content, which makes it easier and less costly to process ores than from the UG2 seam. Production from the UG2 seam began in the 1970s and has steadily increased. The Platreef was mined briefly in the 1920 s, but no significant production occurred until 1993 (Johnson Matthey Plc, 2010). Cawthorn (1999) estimated that about 71 percent of the reserves from the Bushveld Complex are found in the Western limb; 24 percent, in the Eastern limb; and about 5 percent, in the Northern limb and that about 57 percent of the PGM reserves occurred in the Merensky Reef; 38 percent, in the UG2 seam; and 5 percent, in the Platreef.

Higher PGM prices have stimulated interest in exploring for PGMs as extensions to known occurrences at depth, in new areas adjacent to known occurrences within the Bushveld Complex, in reprocessing tailings and waste rock, and for PGMs associated with nickel-copper deposits. New technologies that are able to detect minute levels of PGMs support exploration activities. Future sources of South African PGMs may vary in mineralogy and depth from PGM sources mined in the 20th century as the shallower, lower-cost mineralized portions of the Merensky Reef in the Western limb of the Bushveld Complex are becoming depleted. Much of the future production from the Western limb will likely come from the UG2 seam, which is generally found at a greater depth, has a finer grain size, requires different processing, and generally contains higher rhodium-grade ore than the Merensky Reef. In 1998, the UG2 seam accounted for 38 percent of the ore processed; by 2006, it is estimated that the UG2 seam accounted for about 60 percent of the PGM ore processed in South Africa (Kendall, 2003).

Detailed exploration allows for the delineation of mineralogical differences and the identification of zones with the highest economic potential.

The contribution of PGM reserves in the Eastern and Northern Bushveld has increased relative to the total amount of PGMs produced as exploration has identified additional reserves, and new mines located in these areas have come 


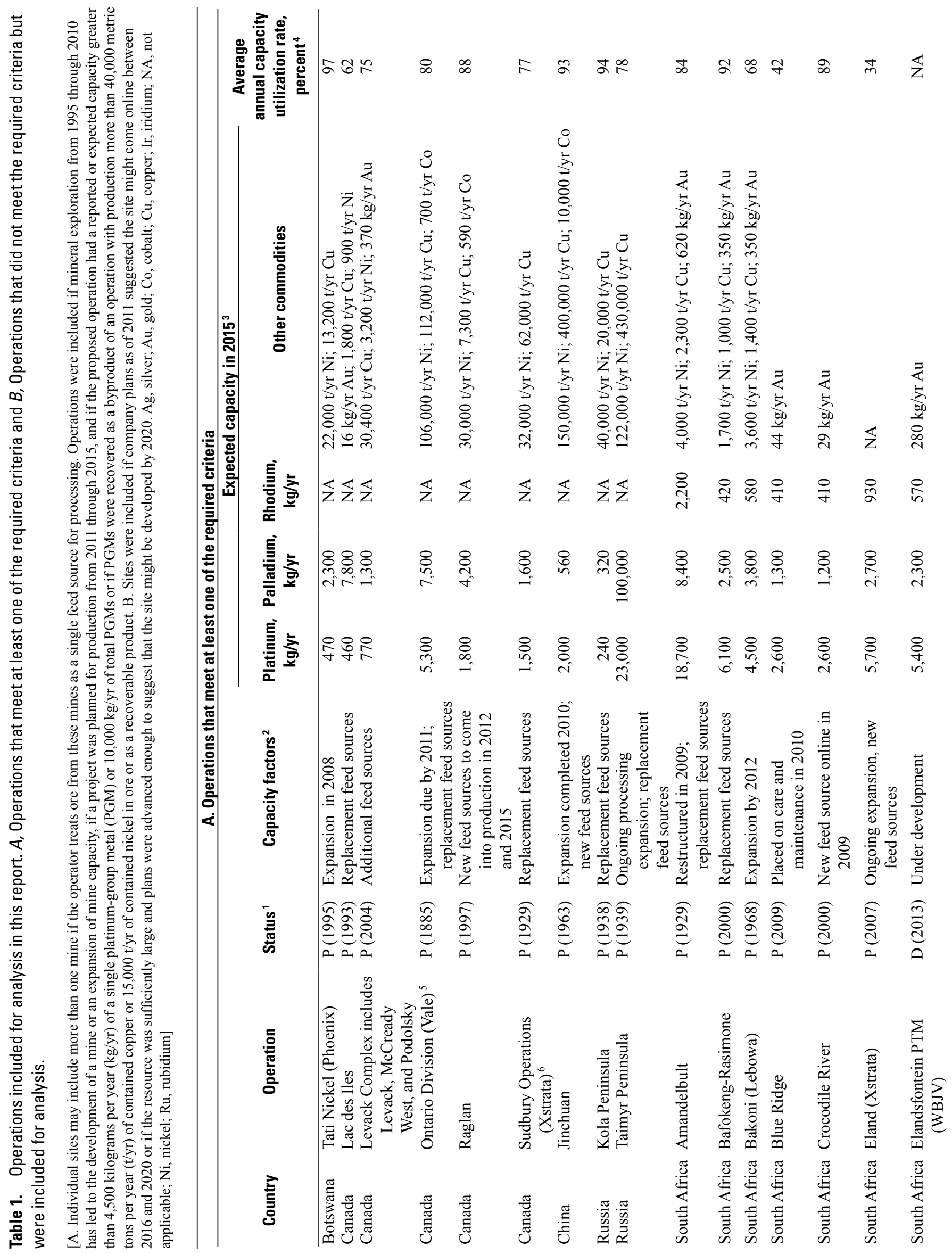



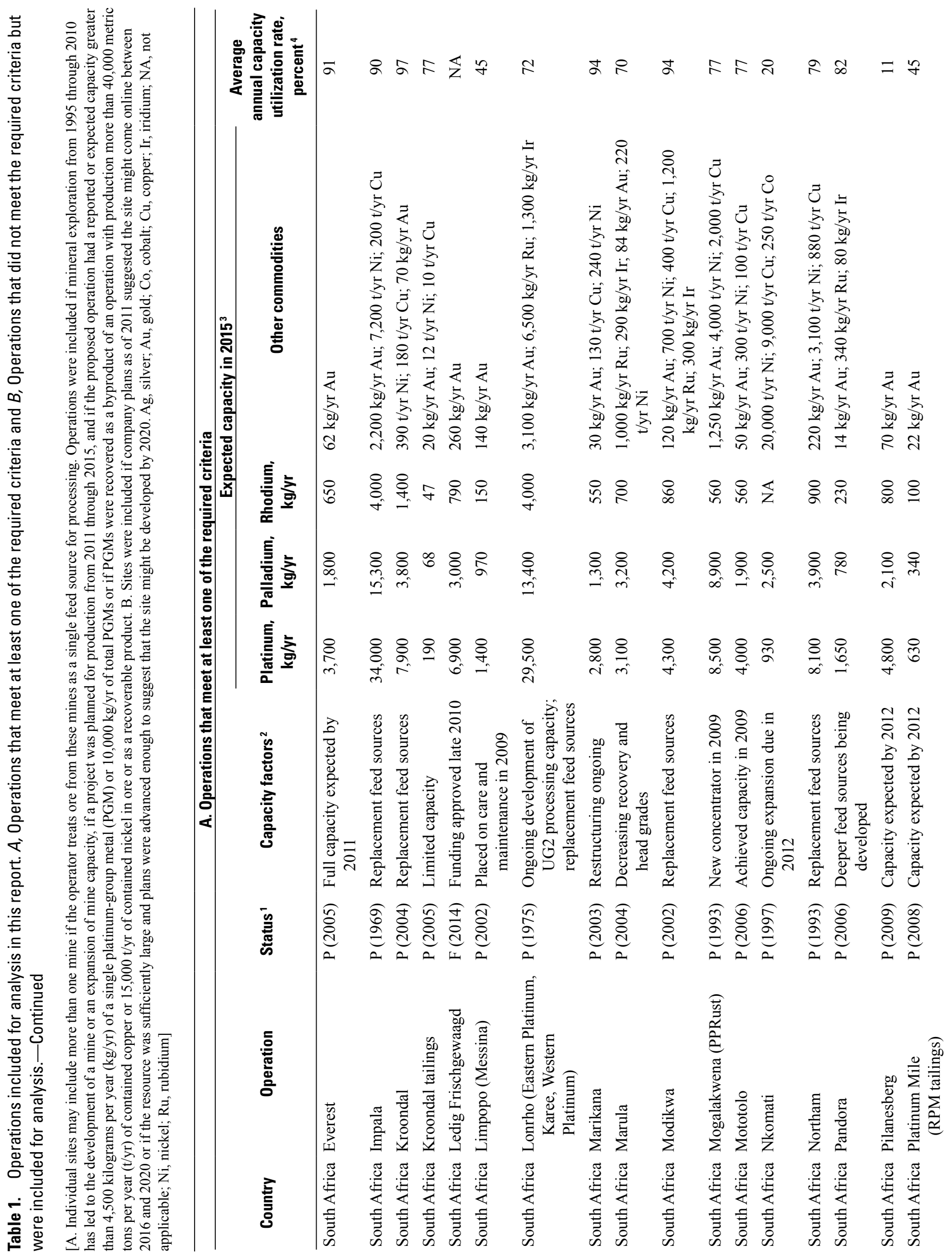


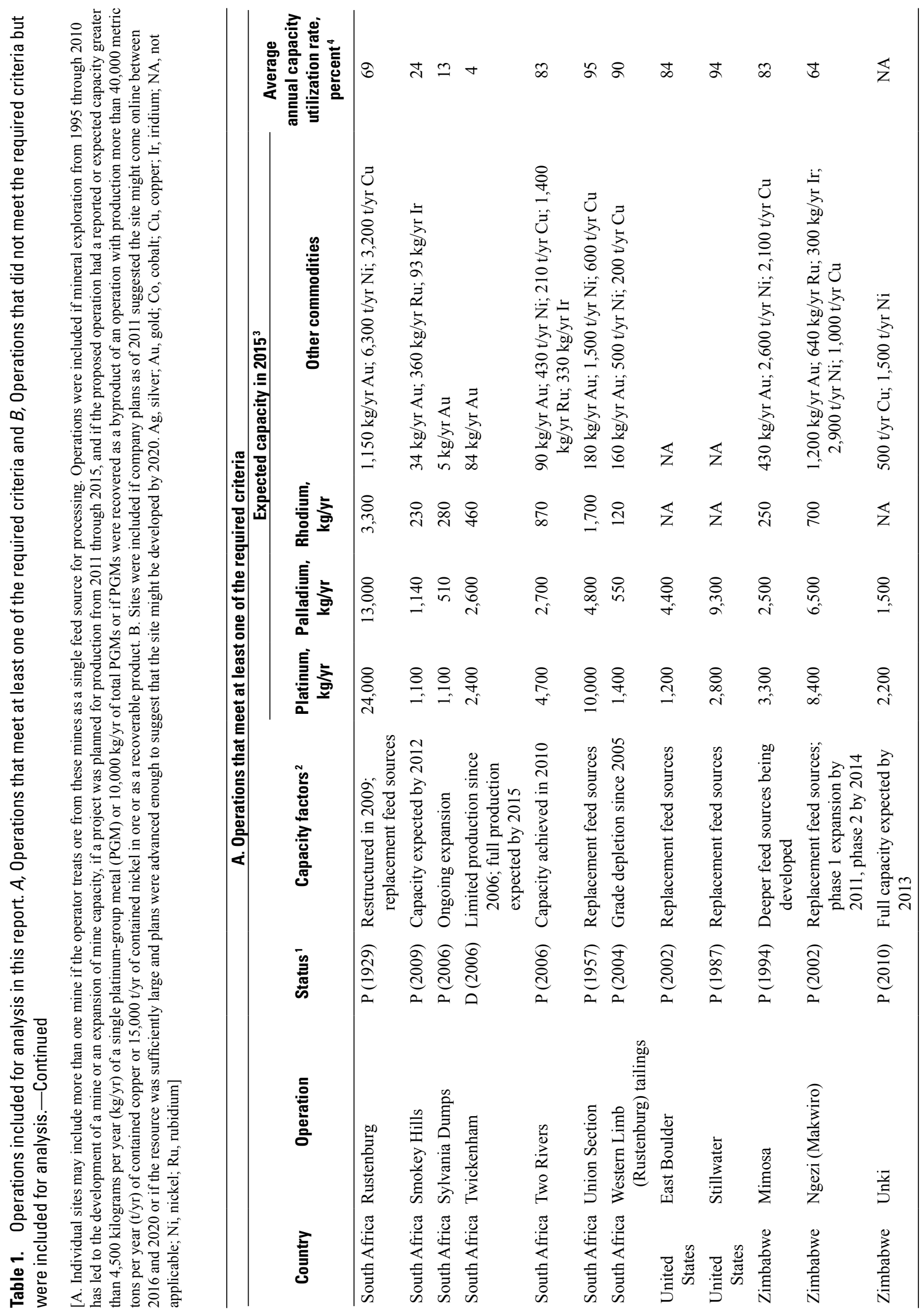




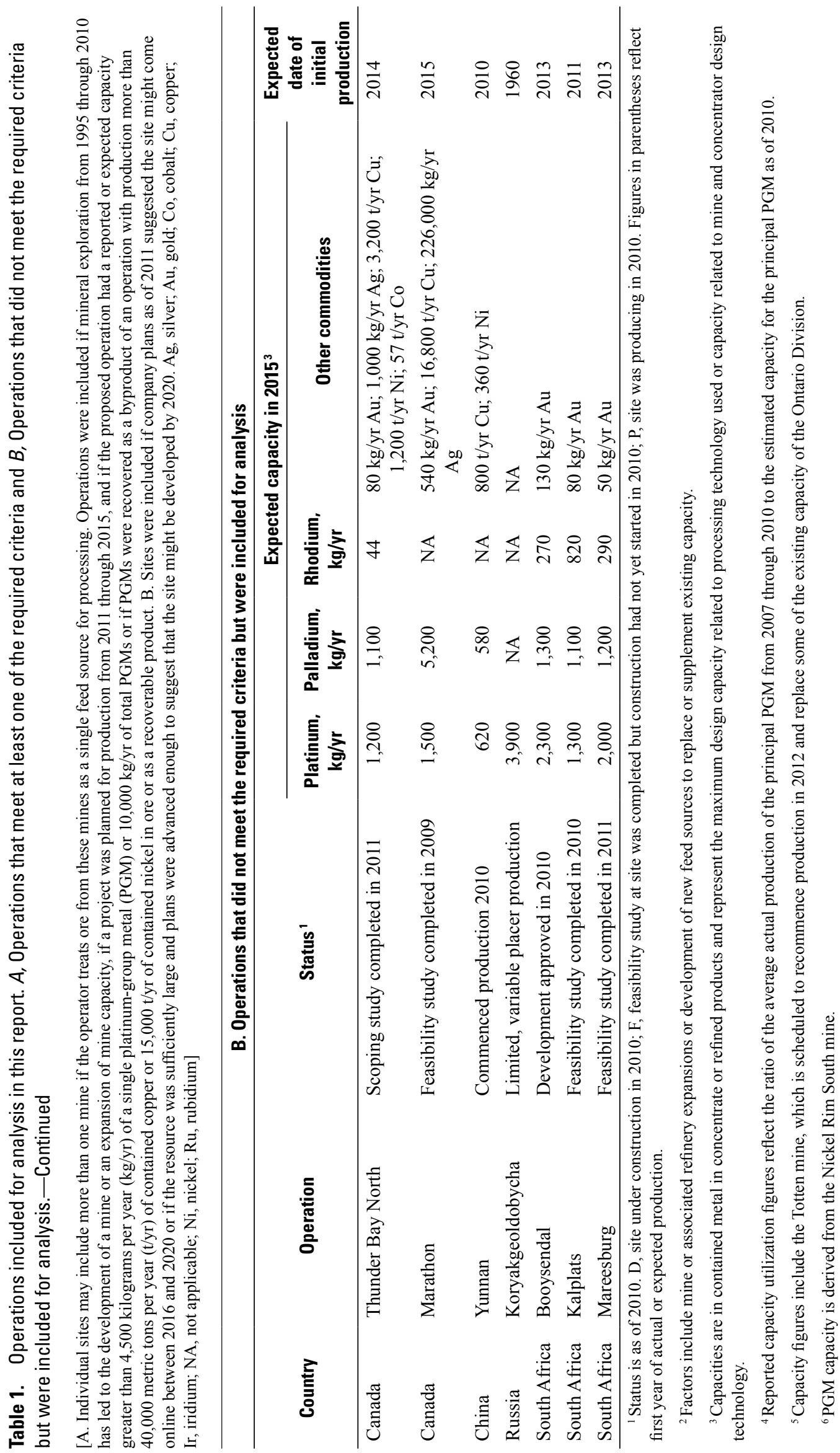


Table 2. Operations not included for statistical analysis in this report but that may become operational between 2016 and 2020.

[Includes sites where the company plans as of 2011 suggested that the site would likely not come into production before 2020 or if expected capacity information was not available or less than the study cutoff level. NA, not available]

\begin{tabular}{|c|c|c|c|c|}
\hline Country & Operation & Reason for exclusion & $\begin{array}{l}\text { Estimated } \\
\text { capacity }\end{array}$ & $\begin{array}{c}\text { Estimated } \\
\text { year of first } \\
\text { production }\end{array}$ \\
\hline Finland & Arctic Platinum & $\begin{array}{l}\text { Ongoing review of prior feasibility studies; production not expected } \\
\text { before } 2015\end{array}$ & 12,800 & NA \\
\hline Russia & Fedorovo Tundra & $\begin{array}{l}\text { Property in feasibility stage; development on hold; production not } \\
\text { expected before } 2015\end{array}$ & 14,700 & NA \\
\hline \multirow{5}{*}{ South Africa } & Genorah (Garatau Tubatse) & Property at feasibility stage; production not expected before 2015 & 12,400 & 2016 \\
\hline & Leeuwkop & $\begin{array}{l}\text { Development delayed beyond 2018; studies to consider project } \\
\text { viability were ongoing }\end{array}$ & 5,300 & NA \\
\hline & Sheba's Ridge & $\begin{array}{l}\text { Development delayed (property considered a lower priority); } \\
\text { production not expected before } 2015\end{array}$ & 10,900 & NA \\
\hline & Nokomis (Maturi Extension) & $\begin{array}{l}\text { Property at prefeasibility stage; production not expected before } \\
2015\end{array}$ & 7,000 & NA \\
\hline & NorthMet & $\begin{array}{l}\text { Property at feasibility stage with ongoing permitting; production } \\
\text { not expected before } 2015\end{array}$ & 3,400 & 2017 \\
\hline
\end{tabular}

${ }^{1}$ Capacity expressed in kilograms of recoverable platinum-group metal.

into production. Table 4 lists the distribution of PGM reserves in 2010 for South African properties mining from the Eastern, Northern, and Western Bushveld in 1995 and 2010 and properties expected to be mined by 2015 . Because criteria used to determine a reserve may vary from operator to operator and site to site, caution should be used when drawing conclusions from the data reported in table 4 . The data reported in table 4 reflect 2010 reserve estimates, so the data do not need to be adjusted for operational or commodity price changes from 1995 to 2010.

For the sites producing in 1995, the Western Bushveld accounted for about 88 percent of the rhodium reserves, 79 percent of the platinum reserves, and 63 percent of the palladium reserves for South Africa, when compiled from company data from 2010; the Eastern Bushveld accounted for about 6 percent of the palladium reserves, 4 percent of the platinum reserves, and 4 percent of the rhodium reserves for the PGM mines in South Africa; and the Northern Bushveld accounted for 31 percent of the palladium reserves, 17 percent of the platinum reserves, and 8 percent of the rhodium reserves. For the sites producing in 2010, the Western Bushveld accounted for about 75 percent of the rhodium reserve, 71 percent of the platinum reserve, and 55 percent of the palladium reserve in South Africa; the Eastern Bushveld contributions increased to about 21 percent of palladium reserves, 19 percent of rhodium reserves, and 16 percent of platinum reserves; and the Northern Bushveld accounted for 22 percent of the palladium reserves, 12 percent of platinum reserves, and 6 percent of the rhodium reserves. When deposits expected to produce by 2015 are included, the Eastern Bushveld would account for an estimated 29 percent of the rhodium reserves, 27 percent of the palladium reserves, and 25 percent of the platinum reserves.

The data on PGM grades compiled for this analysis do not appear to be significantly different from the data compiled by Cawthorn (1999), suggesting that, although mineralogy may change from site to site, between the Merensky Reef and UG2 seam, and between the Eastern Bushveld and the Western Bushveld, the overall distribution of individual PGMs has been found to be reasonably consistent, with an average platinum to palladium ratio of about 1.6 to 1 . Consequently, it is expected that only minor variation in processing technology and recovery rates may occur over the next decade owing to variation in deposit mineralogy as more PGM ore is derived from the Eastern Bushveld.

Figure 3 shows a timeline for the development of additions to platinum capacity from the South African sites considered in this study for the period 1995 through 2015. Development timeframes are noted where capacity changes resulting from new mine production, development of new or replacement ore bodies to feed existing capacity, and (or) mine and refinery expansions have taken place or are planned by 2015. Based on the data reported in figure 3 , the anticipated capacity from the mines considered in this study in 2015 would be nearly twice the capacity available in 1995 . 
Table 3. Operations unlikely to come into production before 2020 .

[Includes sites where company plans as of 2011 suggested that the site would likely not come into production prior to 2020 or if expected capacity information was not available or less than the study cutoff level. NA, not available; kg/yr, kilograms per year; Pt, platinum; Pd, palladium; PGMs, platinum-group metals; ]

\begin{tabular}{|c|c|c|c|}
\hline Country & Operation & Reason for exclusion & $\begin{array}{l}\text { Estimated } \\
\text { capacity }\end{array}$ \\
\hline \multirow[t]{2}{*}{ Australia } & Panton & $\begin{array}{l}\text { Development delayed in } 2008 \text { pending improved economic conditions; status review } \\
\text { planned for } 2011\end{array}$ & 1,600 \\
\hline & Tornio & Property at early exploration stage; production not expected before 2015 & NA \\
\hline Russia & East Pansky & Property at early exploration stage; production not expected before 2015 & NA \\
\hline \multirow{12}{*}{ South Africa } & Der Brochen & Property at prefeasibility stage; production not expected before 2015 & NA \\
\hline & De Wildt & Property at early exploration stage; production not expected before 2015 & NA \\
\hline & Ga-Phasha & Property at prefeasibility stage; production not expected before 2015 & NA \\
\hline & Grootboom & Property at prefeasibility stage; production not expected before 2015 & 2,700 \\
\hline & Kliprivier & Property at early exploration stage; production not expected before 2015 & NA \\
\hline & Kwanda (Platreef) & Property at early exploration stage; production not expected before 2015 & NA \\
\hline & Millennium & Property at early exploration stage; production not expected before 2015 & NA \\
\hline & Mooinooi (Phoenix) & $\begin{array}{l}\text { Property in feasibility stage; production expected in } 2012 \text { but at less than study } \\
\text { cutoff level }\end{array}$ & 390 \\
\hline & Mooiplats & Property at early exploration stage; production not expected before 2015 & NA \\
\hline & M'Phatlele & Development scaled back in 2009; production capacity is less than study cutoff level & 7,800 \\
\hline & Phosiri & Property at early exploration stage; production not expected before 2015 & NA \\
\hline & Rooderand & Property at prefeasibility stage; production not expected before 2015 & 3,600 \\
\hline United States & Birch Lake & $\begin{array}{l}\text { Planned production capacity of } 1,000 \mathrm{~kg} / \mathrm{yr} \text { of } \mathrm{Pt} \text { and } 2,100 \mathrm{~kg} / \mathrm{yr} \text { of } \mathrm{Pd} \text { is below } \\
\text { study cutoff level }\end{array}$ & 3,100 \\
\hline Zimbabwe & Hartley & $\begin{array}{l}\text { Production capacity at time of operation was less than study cutoff level; renewed } \\
\text { production not anticipated }\end{array}$ & NA \\
\hline
\end{tabular}

\footnotetext{
${ }^{1}$ Expressed in kilograms per year of recoverable PGMs.
} 
12 Global Exploration and Production Capacity for Platinum-Group Metals from 1995 though 2015

Table 4. Selected South African platinum-group metal operations and projects.

[PGM, platinum-group metal; Pt, platinum; Pd, palladium; NA, not available]

\begin{tabular}{|c|c|c|c|c|}
\hline \multicolumn{5}{|c|}{ A. Reserves for operations producing or expected to produce PGMs from 1995 through 2015 , in metric tons } \\
\hline \multirow{2}{*}{ Property } & \multicolumn{3}{|c|}{ Reserves $^{1}$} & \multirow{2}{*}{ Pt:Pd } \\
\hline & Platinum & Palladium & Rhodium & \\
\hline Eastern Bushveld, Bakoni (Lebowa) & 164 & 139 & 21 & $1.2: 1$ \\
\hline Northern Bushveld, Mogalakwena (PPRust) & 737 & 817 & 49 & $0.9: 1$ \\
\hline \multicolumn{5}{|l|}{ Western Bushveld: } \\
\hline Amandelbult & 812 & 380 & 152 & $2.1: 1$ \\
\hline Impala & 812 & 435 & 116 & $1.9: 1$ \\
\hline Lonrho & 938 & 424 & 121 & $2.2: 1$ \\
\hline Northam & 152 & 76 & 20 & $2.0: 1$ \\
\hline Rustenburg & 503 & 261 & 67 & $1.9: 1$ \\
\hline
\end{tabular}

Operations producing from 1995 through 2010

Eastern Bushveld:

Blue Ridge ${ }^{2}$

40

Everest $^{3}$

Limpopo (Messina) ${ }^{4}$

Marula $^{5}$

Modikwa $^{4}$

Mototolo $^{6}$

Smokey Hills ${ }^{2}$

Twickenham $^{6}$

Two Rivers ${ }^{7}$

Mpumalanga Province, Nkomati, nickel-copper mine ${ }^{8}$

Western Bushveld:

Bafokeng-Rasimone ${ }^{9}$

Crocodile River ${ }^{9}$

Elandsfontein (Xstrata) ${ }^{7}$

Kroondal ${ }^{5}$

Kroondal tailings ${ }^{3}$

Marikana ${ }^{4}$

Pandora $^{6}$

Pilanesberg $^{2}$

Platinum Mile ${ }^{10}$

Sylvania dump operations ${ }^{6}$

Western limb tailings 5

Total PGM production from 1995 through 2010

37

191

120

35

35

8

169

72

28

347

75

75

28

89

NA

60

36

80

58

NA

$\begin{array}{r}58 \\ \hline 5,909\end{array}$

Operations where PGM production is not expected to begin before $2012^{11}$

Eastern Bushveld:

Booysendal $^{12}$

802

10

401

124

2.0:1

Mareesburg ${ }^{12}$

6

1

1.6:1

2.0:1

1.3:1

1.7:1

0.97:1

$1.7: 1$

1.0:1

0.9:1

$1.7: 1$

$0.4: 1$

$2.2: 1$

$2.4: 1$

2.1:1

1.8:1

NA

1.9:1

2.1:1

2.2:1

$3.2: 1$

NA NA

803

1.6:1 
Table 4. Selected South African platinum-group metal operations and projects.-Continued

[PGM, platinum-group metal; Pd, palladium; Pt, platinum; Rh, rhodium; NA, not available]

\section{A. Reserves for operations producing or expected to produce PGMs from 1995 through 2015, in metric tons}

\begin{tabular}{|c|c|c|c|c|}
\hline Property & \multicolumn{3}{|c|}{ Reserves $^{1}$} & Pt:Pd \\
\hline North West Province, Kalplats, Greenstone deposit ${ }^{13}$ & 56 & 42 & NA & $1.2: 1$ \\
\hline Northern Bushveld, Volspruit ${ }^{13}$ & 64 & 25 & NA & 2.6:1 \\
\hline \multicolumn{5}{|l|}{ Western Bushveld: } \\
\hline Elandsfontein PTM ${ }^{12}$ & 91 & 38 & 9 & $2.4: 1$ \\
\hline Mooinooi (Phoenix) ${ }^{14}$ & 8 & 4 & 2 & 2.1:1 \\
\hline $\begin{array}{l}\text { Total PGM production from reserves of operations producing from } 1995 \\
\text { through } 2010 \text { and expected to be producing by } 2015\end{array}$ & 7,130 & 4,291 & 962 & $1.6: 1$ \\
\hline
\end{tabular}
through 2010 and expected to be producing by 2015

\section{B. Percentages of reserves of PGMs, by region}

\begin{tabular}{|c|c|c|c|c|c|}
\hline & Property & \multicolumn{3}{|c|}{ Percentage of reserves ${ }^{1}$} & Pt:Pd \\
\hline \multicolumn{6}{|c|}{ Operations in the Bushveld Complex in 1995} \\
\hline Eastern Bushveld & & 4 & 6 & 4 & $1.2: 1$ \\
\hline Northern Bushveld & & 17 & 31 & 8 & $0.9: 1$ \\
\hline Western Bushveld & & 79 & 63 & 88 & $2.0: 1$ \\
\hline Eastern Bushveld & & 16 & 21 & 19 & $1.3: 1$ \\
\hline Mpumalanga Province & & 0.55 & 2.30 & NA & $0.4: 1$ \\
\hline Northern Bushveld & & 12 & 22 & 6 & $0.9: 1$ \\
\hline Western Bushveld & & 71 & 55 & 75 & $2.1: 1$ \\
\hline North West Province & & 0.80 & 1 & NA & $1.2: 1$ \\
\hline Northern Bushveld & & 11 & 20 & 5 & $0.9: 1$ \\
\hline Western Bushveld & & 63 & 50 & 66 & $2.0: 1$ \\
\hline
\end{tabular}

${ }^{1}$ Estimates of reserves reported as "proven" or "probable" by the operator and assumed to represent the amount that could be economically extracted at the time of determination.

${ }^{2}$ Production began in 2009

${ }^{3}$ Production began in 2005.

${ }^{4}$ Production began in 2002.

${ }^{5}$ Production began in 2004.

${ }^{6}$ Production began in 2006.

${ }^{7}$ Production began in 2007.

${ }^{8}$ Production began in 1997.

${ }^{9}$ Production began in 2000.

${ }^{10}$ Production began in 2008.

${ }^{11}$ Resource estimates reported as "measured" or "indicated" by the operator based on a level of drilling sufficient to assume continuity between points of observation. Economic viability of the resource has not been determined. These operations were not included in the analysis for this report but were included in this table to show expected changes in reserves or resources of selected metals.

${ }^{12}$ Production expected in 2013.

${ }^{13}$ Production expected in 2014.

${ }^{14}$ Production expected in 2012. 


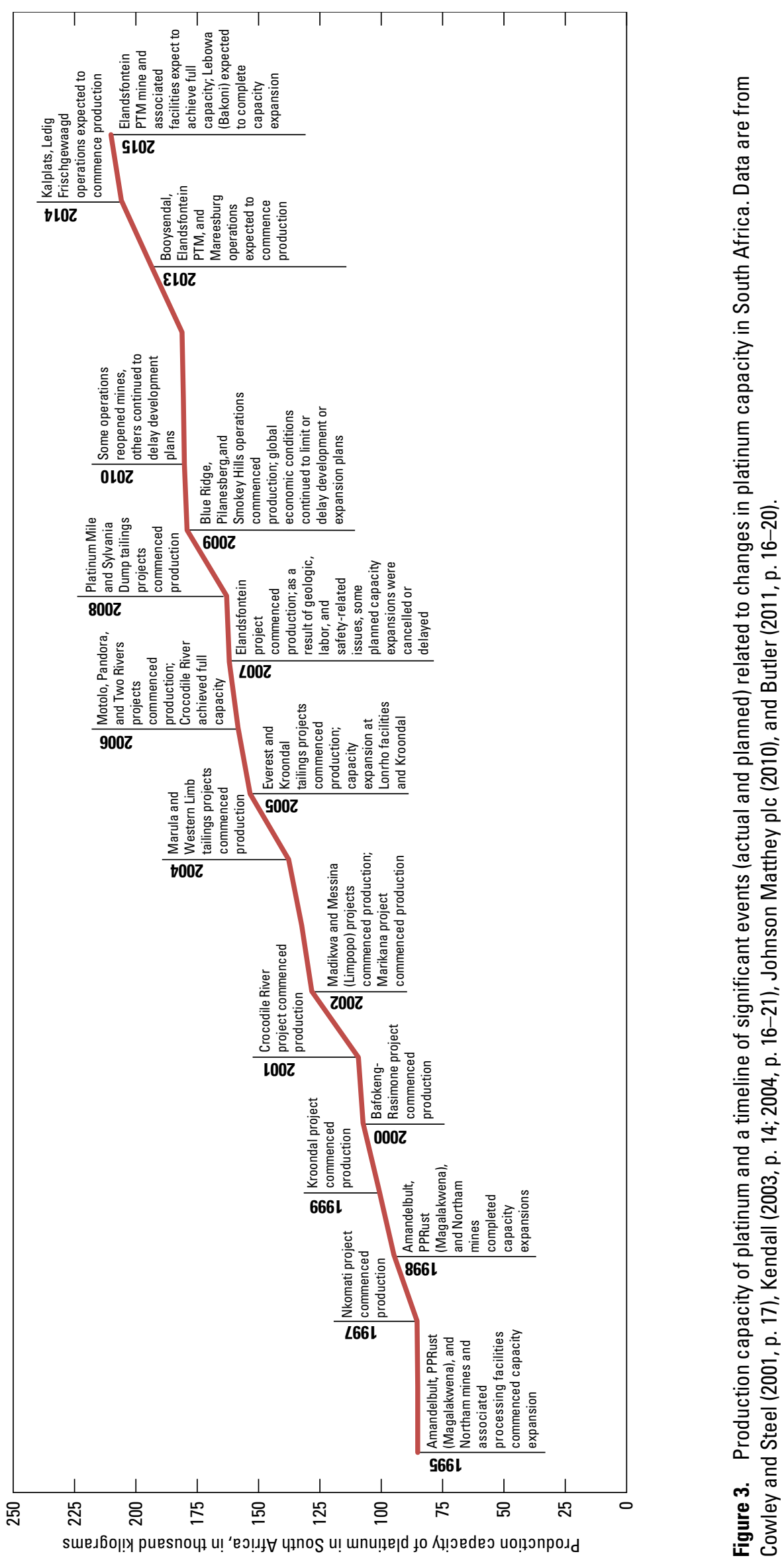


Platinum annual production capacity increased by about $60,000 \mathrm{~kg}$ from 1995 through 2006 as exploration delineated new areas, new projects were brought into production, and some operating mines were expanded. The total South African platinum capacity increased by about 50 percent during this period.

Platinum annual production capacity increased by about $18,000 \mathrm{~kg}$ from 2007 through 2010. The overall increase was lower than previously forecast by operators because of domestic energy shortages, labor and safety issues, increased costs associated with the mining of deeper deposits, as well as the effects of the global economic recession of 2008 and 2009 on the demand for industrial products and vehicles that use PGMs for components which led to temporary mine closures and delays in mine expansion and development. These conditions encouraged many companies to reduce or curtail mineral production and delay mine expansion and development plans until the global economy began to recover and industrial demand again began to increase. Based on data compiled from industry sources by the USGS, the estimated capacity utilization rate of South African PGM mines decreased from 96 percent in 2006 to 73 percent in 2010.

Although plans for some project expansions or new development were delayed, exploration or development of a few advanced-stage projects with committed funding continued. Some mines reopened in 2010, while others were reevaluating production or development plans. A few projects were expected to come online from 2011 and 2015, although development of other projects would be deferred beyond 2015. The data collected during this study suggest that the annual platinum capacity in South Africa would increase by about 24,000 kg from 2011 through 2015. This represents an increase of about 13 percent from South Africa's platinum production capacity in 2010 .

PGMs recovered from South Africa are derived from a mix of large, well-established integrated operations managed by large companies and newer, smaller mines operated under joint-venture agreements between major producers and junior companies. Because the PGM-rich areas of South Africa have been identified since the 1920s and have been well explored, exploration associated with the deposits developed since 1995 has focused on delineating replacement ore zones adjacent to producing areas and updating reserve estimates for mineralized zones at depth. A discussion of the principal mines and developing deposits in South Africa follows.

Anglo Platinum Limited (Anglo) is the world's leading producer of PGMs and accounted for about 42 percent of the world's platinum production and about 22 percent of the world's palladium production in 2010 (Anglo Platinum Limited, 2010). The company's interests in South Africa included the Rustenburg operation, the Amandelbult operation, the Mogalakwena (PPRust) mine, the Twickenham mine, and the Western limb tailings project. The Rustenburg operation opened in 1929 on the Western Bushveld and, in 2010, had a capacity of about $40,000 \mathrm{~kg} / \mathrm{yr}$ of recoverable PGMs (table 1) from the Bathopele, Khomanani, Khuseleka, Siphumelele, and Thembelani mines. The Amandelbult operation opened in 1929 on the Western Bushveld and, in 2010, had a capacity of $29,000 \mathrm{~kg} / \mathrm{yr}$ of recoverable PGMs from the Dishaba and Tumela mines. The Mogalakwena (PPRust) mine opened in 1993 on the Northern Bushveld and, in 2010,had a capacity of $18,000 \mathrm{~kg} / \mathrm{yr}$ of recoverable PGMs. The Twickenham mine opened in 2005 on the Eastern Bushveld as a pilot plant and, in 2010, had a capacity of $670 \mathrm{~kg} / \mathrm{yr}$ of recoverable PGMs; full capacity at the Twickenham mine was expected to be $5,500 \mathrm{~kg} / \mathrm{yr}$ of recoverable PGMs by 2015. The Western limb tailings project opened in 2004 to recover PGMs from tailings derived from mining the Western Bushveld and, in 2010, had a capacity of 2,100 kg/yr of recoverable PGMs. Ore from these operations feeds company-operated concentrating facilities, smelters, and refineries in South Africa.

In addition, Anglo has a number of joint-venture projects. The Union Section mine opened in 1957 on the Western Bushveld and, in 2010, had a capacity of $16,500 \mathrm{~kg} / \mathrm{yr}$ of recoverable PGMs. The Bokoni (Lebowa) mine opened in 1969 on the Eastern Bushveld and, in 2010, had a capacity of $7,300 \mathrm{~kg} / \mathrm{yr}$ of recoverable PGMs; capacity was expected to increase to $8,900 \mathrm{~kg} / \mathrm{yr}$ of recoverable PGMs by 2014 . The Bafokeng-Rasimone mine opened in 1999 on the Western Bushveld and, in 2010, had a capacity of $9,000 \mathrm{~kg} / \mathrm{yr}$ of recoverable PGMs. The Marikana mine opened in 2002 on the Western Bushveld and, in 2010, had a capacity of $4,700 \mathrm{~kg} / \mathrm{yr}$ of recoverable PGMs. The Modikwa mine opened in 2002 on the Eastern Bushveld and, in 2010, had a capacity of $9,400 \mathrm{~kg} / \mathrm{yr}$ of recoverable PGMs. The Kroondal mine opened in 2004 on the Western Bushveld and, in 2010, had a capacity of $13,100 \mathrm{~kg} / \mathrm{yr}$ of recoverable PGMs. The Mototolo mine opened in 2006 on the Eastern Bushveld and, in 2010, had a capacity of $6,500 \mathrm{~kg} / \mathrm{yr}$ of recoverable PGMs. The Pandora mine opened in 2006 on the Western Bushveld and, in 2010 , had a capacity of $3,100 \mathrm{~kg} / \mathrm{yr}$ of recoverable PGMs.

Exploration activities from 1995 through 2009 provided sufficient data to justify development of seven new mines and one tailings reprocessing facility with a combined capacity of $62,400 \mathrm{~kg} / \mathrm{yr}$ of recoverable PGMs. In addition, the company has a number of projects at the prefeasibility or feasibility stages, but none of them are expected to come into production before 2015. The Styldrift project is perhaps the most advanced, and could potentially produce $7,600 \mathrm{~kg} / \mathrm{yr}$ of recoverable PGMs; however, initial production is not planned before 2017. The company's smelting and refining operations, wholly owned and located in South Africa, were upgraded or expanded at various times during the study period to accommodate the expanded capacity from company-owned and joint-venture mines (Anglo Platinum Limited, 2010).

Impala Platinum Holdings Limited (Impala) is South Africa's second leading vertically integrated PGM producer. The Impala mine, the company's leading producer, opened in 1969 on the Western Bushveld and, in 2010, had a capacity of $53,300 \mathrm{~kg} / \mathrm{yr}$ of recoverable PGMs. The Marula mine opened in 2004 on the Eastern Bushveld and, in 2010, had a capacity of 7,000 kg/yr of recoverable PGMs. Impala is a joint-venture 
partner with African Rainbow Minerals Limited on the Two Rivers mine, which opened in 2006 on the Eastern Bushveld and, in 2010 , had a capacity of $7,700 \mathrm{~kg} / \mathrm{yr}$ of recoverable PGMs. An expansion to $10,000 \mathrm{~kg} / \mathrm{yr}$ of recoverable PGMs is planned by 2013 (Smit, 2010). Impala manages the Leeuwkop project that is currently in the feasibility stage; the project was not expected to produce before 2015. Impala also operates two PGM mines in Zimbabwe (Impala Platinum Holdings Limited, 2010).

Lonmin plc is the world's third leading verticallyintegrated PGM producer. Approximately 92 percent of Lonmin's production comes from the Lonrho Platinum Division, supplied by the Eastern Platinum, Karee, and Western Platinum mines in the Marikana area. The Western Platinum operation opened in 1975 on the Western Bushveld, the Eastern Platinum operation opened in 1989, and the Karee mine opened in 1990, at which point, the three operations were integrated into a single operation. In 2010, the operation had a combined capacity of $54,700 \mathrm{~kg} / \mathrm{yr}$ of recoverable PGMs. The company operated the Limpopo (Messina) mine, which opened in 2002 on the Eastern Bushveld and, in 2010, had a capacity of $2,500 \mathrm{~kg} / \mathrm{yr}$ of recoverable PGMs. The mine was placed on care and maintenance in 2009. The company was conducting ongoing exploration for additional resources and was involved in a joint-venture agreement associated with the Pandora mine and several PGM exploration and development projects in South Africa (Lonmin plc, 2010).

Platmin Limited is a mid-tier producer of PGMs in South Africa. The company's primary asset is the Pilanesberg mine, which opened in 2009 on the Western Bushveld and, in 2010, production was increasing to reach the design capacity of $7,700 \mathrm{~kg} / \mathrm{yr}$ of recoverable PGMs by 2012. The company was also involved in joint-venture agreements associated with the Mphahlele PGM project, in which a feasibility study assessed a 7,800-kg/yr PGM operation, and several early-stage PGM exploration projects in South Africa (Platmin Limited, 2010).

Aquarius Platinum Limited is a mid-tier producer of PGMs with interests in seven operating mines in South Africa and Zimbabwe. In South Africa, it operates the Everest mine, which opened in 2005 on the Eastern Bushveld and, in 2010 , had a capacity of $6,200 \mathrm{~kg} / \mathrm{yr}$ of recoverable PGMs. The company operates the Kroondal and Marikana mines under a joint-venture agreement with Anglo. It also manages the Kroondal tailings project, which opened in 2005 on the Western Bushveld and, in 2010, had a capacity of $310 \mathrm{~kg} / \mathrm{yr}$ of recoverable PGMs, under a joint-venture agreement with Sylvania Resources Limited and Ivanhoe Nickel and Platinum Limited. Aquarius Platinum Limited has a joint-venture agreement with Mvelaphanda Holdings (Pty.) Limited to operate the Platinum Mile mine (Rustenberg platinum minetailings), which opened in 2008 on the Western Bushveld and is expected to achieve a capacity of $1,100 \mathrm{~kg} / \mathrm{yr}$ of recoverable PGMs by 2012.In 2009, the company opened the Blue Ridge mine on the Eastern Bushveld, which is being developed with a capacity of $4,300 \mathrm{~kg} / \mathrm{yr}$ of recoverable PGMs by 2012. Since 1995, the company has increased its refining capacity by $12,700 \mathrm{~kg} / \mathrm{yr}$ to accommodate increased production from new or expanded mining operations and PGM tailings operations. In addition to ongoing exploration activities associated with its producing operations, the company is managing exploration and development activities at the Sheba's Ridge project. A 2008 feasibility study considered an operation with a capacity of $10,900 \mathrm{~kg} / \mathrm{yr}$ of recoverable PGMs (Aquarius Platinum Limited, 2010). Initial production would likely occur after 2015.

Xstrata plc. became a mid-tier PGM producer in 2007 when it acquired Eland Platinum Holdings Limited and its assets, including the Eland mine (formerly called Elandsfontein). The mine opened in 2007 on the Western Bushveld and had an initial capacity of $4,100 \mathrm{~kg} / \mathrm{yr}$ of recoverable PGMs. The company was planning an expansion of the mine and associated processing operations, which would increase the capacity to $9,300 \mathrm{~kg} / \mathrm{yr}$ of recoverable PGMs by 2015, but development was delayed owing to difficulties in securing mining rights. The company has jointventure agreements with Anglo to operate the Mototolo mine and with Nkwe Platinum Limited to conduct exploration and development activities at the Genorah Farms and Tubatse projects. A feasibility study in 2010 evaluated a combined operation capable of producing up to $12,400 \mathrm{~kg} / \mathrm{yr}$ of recoverable PGMs. It is not expected that this operation would commence production before 2015 (Xstrata plc, 2010).

Northam Platinum Limited is an independent integrated PGM producer conducting ongoing exploration activities and operating the Northam mine, which opened in 1993 on the Western Bushveld and, in 2010, had a capacity of $12,900 \mathrm{~kg} / \mathrm{yr}$ of recoverable PGMs. The company is developing the Booysendal project on the Eastern Bushveld. The plan for the mine in 2010 envisioned initiation of a phase 1 production in 2013 with an expected capacity of $3,900 \mathrm{~kg} / \mathrm{yr}$ of recoverable PGMs; a phase 2 operation, bringing capacity to $7,600 \mathrm{~kg} / \mathrm{yr}$ of recoverable PGMs, was planned for 2016 (Northam Platinum Limited, 2010).

Eastern Platinum Limited is a junior PGM producer that operates the Crocodile River mine. The mine opened in 2000 on the Western Bushveld and, in 2010, had a capacity of 4,100 kg/yr of recoverable PGMs. The company managed several exploration and development projects on the Eastern Bushveld. The first project under development is the Mareesburg project, which was expected to begin production in early 2013 at a capacity of $3,500 \mathrm{~kg} / \mathrm{yr}$ of recoverable PGMs (Eastern Platinum Limited, 2010).

African Rainbow Minerals Limited is a junior South African minerals company that is participating in a series of joint-venture agreements. The company has entered a jointventure agreement with MMC Norilsk Nickel in Mpumalanga Province on the Nkomati nickel-copper-chrome-PGM mine, which opened in 1997 and which, after completion of an expansion project in 2010, has a capacity of 3,400 kg/yr of recoverable PGMs. The company also has joint- venture agreements with Anglo to operate the Modikwa mine, with Impala to operate the Two Rivers mine, and with Platinum 
Australia Limited on the Kalplats project, a feasibility-stage PGM project in the Kraaipan Greenstone Belt with a planned capacity of 3,200 kg/yr of recoverable PGMs (African

Rainbow Minerals Limited, 2010).

Wesizwe Platinum Limited is a junior South African PGM company managing the exploration and development activities of the Ledig Frischgewaagd project on the Western Bushveld. The company secured financing for development at the end of 2010, was planning initial production in 2014, and anticipated achieving a capacity of $10,700 \mathrm{~kg} / \mathrm{yr}$ of recoverable PGMs by 2019 (Wesizwe Platinum Limited, 2010). The company is involved in a joint venture with Platinum Metals Group Limited to explore and develop the Elandsfontein PTM (WBJV) project on the Western Bushveld by 2013. This project will have an estimated capacity of 8,300 $\mathrm{kg} / \mathrm{yr}$ of recoverable PGMs.

Platinum Australia Limited is a junior PGM company, which opened the Smokey Hills mine on the Eastern Bushveld in 2009. The company expected the mine to reach its full capacity of $2,900 \mathrm{~kg} / \mathrm{yr}$ of recoverable PGMs by 2012. The company is involved in a joint venture to explore the Rooderand project on the Western Bushveld, an earlystage exploration project that is not expected to commence production before 2015 (Platinum Australia Limited, 2010).

Sylvania Platinum Limited was conducting exploration and prefeasibility work at the Volspruit project. The company planned to begin a feasibility study in 2011 for a $4,400-\mathrm{kg} / \mathrm{yr}$ PGM operation targeted for initial production in 2014, but significant production before 2015 was not likely to take place (McConnachie, 2010)

\section{Russia}

The USGS estimated that about 13 percent of the global platinum production and 42 percent of global palladium production came from Russia in 2010. Despite the importance of the Russian PGM production on global markets, useful information on PGM reserves, production, and sales have historically been difficult to acquire because data were deemed to be confidential under the Russian state secrecy law until 2005, when portions of this law were repealed (Levine, Brininstool, and Wallace, 2010). MMC Norilsk Nickel (Norilsk Nickel) produces about 95 percent of the PGMs recovered in Russia from the nickel-copper sulfide deposits in the Noril'sk-Talnakh area of Siberia and the Kola Peninsula.

Norilsk Nickel produces copper, nickel, PGMs, and other metals in two areas of Russia. The Polar Division is the largest and operates seven producing mines and two metallurgical processing plants in the Noril'sk-Talnakh area of the Taimyr Peninsula to produce nickel and copper cathodes, cobalt matte, and PGM concentrate. For this study, the seven mines considered part of the Polar Division (Komsomolsky, Mayak, Medvezhy Ruchey, Oktyabrsky, Skalisty, Talmyrsky, and Zapolyarny) have been combined as the Taimyr Peninsula operation because individual mine statistics are not reported separately. The Kola Division of Norilsk Nickel operated three mines and a metallurgical processing facility on the Kola Peninsula to produce nickel and copper cathodes, carbonyl nickel, and cobalt and PGM concentrate. For this study, the three mines included in the Kola Division (Kaula-Kotselvaara, Severny, and Tsentralny) have been combined as the Kola Peninsula operation (MMC Norilsk Nickel, 2010c).

The Noril'sk-Talnakh ore bodies are hosted in a sequence of layered ultramafic sills. Although thicker than the reefs mined in South Africa, they are more variable in grade and PGM composition, and the palladium grade is generally higher than in the Bushveld Complex. Three types of ore are mined:

- massive nickel-rich sulfide ores with a typical PGM content ranging from 9 to 13 grams per metric ton $(\mathrm{g} / \mathrm{t})$ with a palladium-to-platinum ratio from $3: 1$ to $4: 1$

- cuprous sulfide ores with a typical PGM content ranging from 8 to $11 \mathrm{~g} / \mathrm{t}$ and a palladium-to-platinum ratio from $4: 1$ to $4.5: 1$

- sulfide ores hosting disseminated PGMs with a typical PGM content ranging from 3 to $9 \mathrm{~g} / \mathrm{t}$ and a palladium-toplatinum ratio from $2.5: 1$ to $3.6: 1$

The identified resources in the region have been classified as 70 percent disseminated, 16 percent nickel-rich, 9 percent cuprous, and 5 percent pyrrhotitic tailings (Levine and Wilburn, 2003).

Continued exploration in an established mining district can lead to the discovery of additional ore zones and expansion or further delineation of deposits. Changes in the global economy and markets can result in a shift in demand for individual metals, and mining operations that are best positioned to adjust to such changes in metal demand have an economic advantage. Consequently, it is essential for a company such as Norilsk Nickel that produces a variety of metals from multiple sources to efficiently use exploration data to identify ore zones that have the greatest potential to maximize profit without compromising the integrity of the ore body and to adjust mining activities to meet this changing metal demand.

Most of the district's base-metal production since World War II originated from the mining of nickel-rich ores, of which PGMs accounted for about 24 percent of the value of the ore. Although PGM grades may have been significant, PGMs were a minor byproduct of base-metal production. From 1998 through 2001, prices for PGMs, most notably palladium, increased, thereby increasing the value of the PGMs in the ore and making it economical to mine the disseminated ore at the older mines for PGMs, which accounted for about 54 percent of ore value from this type of deposit. In 2000, nickel-rich ores constituted 79 percent of the Polar Division's PGM production by weight, cuprous ores accounted for about 11 percent, disseminated ores accounted for about 10 percent, and pyrrhotitic tailings accounted for a negligible amount of production (Levine and Wilburn, 2003). By 2010, about 43 percent of the production from the Polar Division was derived from nickel-rich ores, 35 percent came from cuprous ores, and 22 percent came from disseminated ores (MMC Norilsk Nickel, 2010b). In 2010, PGMs accounted for about 
25 percent of the total value of mine production for the Polar Division. By 2015, the distribution of ore production was expected to be 34 percent nickel-rich ores, 31 percent cuprous ores, and 35 percent disseminated ores, so PGMs are expected to contribute a greater percentage of the total value of mine production than in 2010 .

Several significant changes occurred from 1995 through 2010 at the Polar Division mines. In addition to continued base-metal recovery, Norilsk Nickel placed an increased emphasis on recovering PGMs. There was a gradual shift from mining nickel-rich ore to cuprous ore at the Oktyabrsky mine, and there was an increase in production of disseminated ores from the Medvezhy Ruchey and Zapolyarny mines. The nickel-rich Skalisty mine came into production in 1997 and reached a capacity of 2 million metric tons per year of ore in 2005 (MMC Norilsk Nickel, 2010b).

Based on Norilsk Nickel's production plan to 2025, the most significant changes expected from 2010 through 2014 for the Taimyr Peninsula operations would be an increase in production of disseminated ore from the Komsomolsky mine and nickel-rich ore from the Skalisty mine and an anticipated decrease in production of disseminated ore from the Medvezhy Ruchey mine (MMC Norilsk Nickel, 2010b). If the expected changes occur, then the overall PGM capacity at the Taimyr Peninsula operations would increase by about $26,000 \mathrm{~kg} / \mathrm{yr}$, or 8 percent, by 2015 . The percentage of production of PGMs from disseminated ore, which derives more than one-half of its value from these metals, would be greater than either nickel-rich ore or cuprous ore by 2015.

The most significant changes that occurred during the study period at the Kola Peninsula operations included the development of replacement feed sources for mines nearing depletion. The newer mines were generally at greater depths and of higher grade than the sources being replaced; there was increased processing of low-grade ores to optimize capacity loading at the concentrator stage. (MMC Norilsk Nickel, 2010b).

As much as $10,000 \mathrm{~kg} / \mathrm{yr}$ of platinum has historically been recovered from placer deposits in the Ural Mountains and Siberia, mined by small private production companies called artels (Levine, Brininstool, and Wallace, 2010). Production of platinum from alluvial placer deposits in Siberia, the leading of which is Koryakgeoldobycha, has generally been stable in the 3,000- to $4,000-\mathrm{kg} / \mathrm{yr}$ of platinum range since 1990 . Based on current trends, future production from this area should continue at this level at least until 2015. A feasibility study was conducted by Barrick Gold Corporation on the Fedorovo Tundra project in 2008 for an operation capable of yielding up to $14,700 \mathrm{~kg} / \mathrm{yr}$ of recoverable PGMs. Development of the project was suspended in 2009. PGM production from alluvial placers in the Ural Mountains was thought to be less than $350 \mathrm{~kg} / \mathrm{yr}$. Sustained production from individual placer deposits in Russia was below the cutoff level used in this study so these deposits were not included for analysis.

With the long history of nickel-copper production in the Noril'sk-Talnakh region and the relatively low historical recovery of PGMs from established mines, the accumulation of mine waste stockpiles and mill tailings have become an important source of PGMs in Russia, especially during periods of high PGM prices. Norilsk Nickel began recovering PGMs from mill tailings about 1999, and additional concentrator capacity was being allocated to process stockpiled pyrrhotitic tailings with an average PGM content of about $8 \mathrm{~g} / \mathrm{t}$ (Levine and Wilburn, 2003).

\section{Zimbabwe}

PGMs were discovered in the Great Dyke of Zimbabwe during the early 20th century at about the same time as the discovery of the Bushveld Complex in neighboring South Africa. The first commercial production of PGMs from the Great Dyke occurred with the opening of the Hartley mine in 1997. The mine operated until 1999 when it was closed owing to engineering problems and low productivity. Union Carbide Corporation commenced a small pilot operation at the Mimosa mine in 1994. Mimosa Investments Limited, a joint venture between Impala and Aquarius, purchased rights to the property in 2001-02 and placed the site into production. Capacity had reached about $5,750 \mathrm{~kg} / \mathrm{yr}$ of recoverable PGMs by 2010 and was expected to have a capacity of $6,100 \mathrm{~kg} / \mathrm{yr}$ of recoverable PGMs by 2014. The Ngezi mine is operated by a subsidiary of Impala and commenced production in 2002. A phase 1 expansion program designed to phase out the open pit mining in favor of underground mining was completed in 2010 , increasing production capacity to $10,500 \mathrm{~kg} / \mathrm{yr}$ of recoverable PGMs. A phase 2 expansion to increase capacity to $16,500 \mathrm{~kg} / \mathrm{yr}$ of recoverable PGMs was expected to be completed by 2014 (Butler, 2011, p. 22). The Unki project, owned by Anglo, commenced production at the end of 2010; by 2014 , production capacity was expected to be $3,700 \mathrm{~kg} / \mathrm{yr}$ of recoverable PGMs.

Investment in PGM mining in Zimbabwe was gradual during the study period, inhibited in part by an uncertain political climate. Legislation proposed in 2010 that would require that large corporations have 51 percent domestic ownership has continued this uncertainty, causing Fraser Institute to rank Zimbabwe last in the "Uncertainty Concerning the Administration, Interpretation, and Enforcement of Existing Regulations" category of its 2009/2010 annual survey (McMahon and Cervantes, 2010, p. 24).

\section{Canada}

Most of the PGMs recovered from mining in Canada are byproducts of nickel-copper ores in the Sudbury Basin in Ontario. Palladium is the predominant PGM, with platinum the subordinate commodity. Mining in the region began as early as 1885 , but it was not until 1908 that commercial production of PGMs began by International Nickel Company [which became Inco and is now owned by Companhia 
Vale do Rio Doce (Vale)]. In 1924, Inco opened a refinery at Acton, United Kingdom, to refine the PGMs contained in copper matte from the Sudbury Basin. As of 2009, the Ontario Division of Vale recovered PGMs from six nickelcopper mines with a combined capacity of $12,800 \mathrm{~kg} / \mathrm{yr}$ of recoverable PGMs. Vale is redeveloping the Totten mine to replace a portion of the capacity of the Ontario Division after full production is achieved in 2013; the redevelopment would allow up to 2,500 kg/yr of refined PGMs to be recovered from the nickel-copper ores at Totten.

Mining of PGMs contained in nickel-copper ores from the Sudbury Basin by Falconbridge Limited began in 1927; Falconbridge was acquired by Xstrata plc in 2006. PGMs are recovered at the Nikkelverk refinery in Norway. The Sudbury operations of Xstrata have historically consisted of multiple mines producing copper, nickel, and PGMs. By 2009, however, because of poor economic conditions and declining ore grades, these operations were restructured so that the Nickel Rim South mine would be the only source of PGMs. The Nickel Rim South mine commenced production in 2009 and was expected to recover up to $3,100 \mathrm{~kg} / \mathrm{yr}$ of recoverable PGMs from nickel-copper matte by 2011 (Xstrata plc, 2010, p. 14).

The Lac des Iles mine, operated by North American Palladium Ltd., is the only Canadian mine where PGMs are the primary product. Commercial open pit production commenced in 1993; underground mining commenced in 2005 to recover PGMs from a deeper, higher grade deposit. Before being placed on care and maintenance in 2008 owing to global economic conditions, the mine had produced up to $9,700 \mathrm{~kg}$ of PGMs annually. Mining resumed in 2010 after PGM prices increased. A new underground zone was being developed that was expected to reach a capacity of $8,300 \mathrm{~kg} /$ yr of recoverable PGMs by 2013 (North American Palladium Ltd., 2010).

Another source of PGMs in Canada is the Raglan nickelcopper mine operated by Xstrata, which opened in 1997 on the Nunavik Peninsula in Quebec. In 2010, the mine had a capacity of about $3,900 \mathrm{~kg} / \mathrm{yr}$ of recoverable PGMs. If ore from a newly identified zone is developed as planned, new feed sources would come into production in 2012, 2014, and 2016, and PGM capacity would increase to $6,000 \mathrm{~kg} / \mathrm{yr}$ of recoverable PGMs by the end of 2016 (Xstrata plc, 2011, p. 22).

The Levack Complex nickel-copper deposits in the Sudbury Basin was developed by FNX Mining Company Inc. (which merged with Quadra Mining Ltd. in 2010 to form Quadra FNX Mining Ltd.] and began production in 2004. PGMs are currently recovered from ore mined from the Levack, McCreedy West, and Podolsky deposits with an estimated capacity of 2,100 kg/yr of recoverable PGMs in 2010 (FNX Mining Company Inc., 2010).

With its purchase of Marathon PGM Corporation in 2010, Stillwater Mining Company announced plans to pursue the development of the Marathon PGM property in Ontario. Based on a 2010 feasibility study update, the operation would have a capacity of 7,600 kg/yr of recoverable PGMs.
Production at the site was estimated to begin in 2013, and full production would likely be achieved after 2015 (Murahwa and others, 2010).

Magma Metals Limited was conducting ongoing exploration at the Thunder Bay North project in Ontario. This prefeasibility-stage project was planned to have a capacity of $1,200 \mathrm{~kg} / \mathrm{yr}$ of recoverable platinum and $1,100 \mathrm{~kg} / \mathrm{yr}$ of recoverable palladium. Initial production could occur as early as 2014 (Magma Metals Limited, 2011).

\section{United States}

Virtually all the PGM production in the United States comes from the Stillwater Complex in Montana. Two PGM mines (the Stillwater and the East Boulder mines) are currently in production, both operated by Stillwater Mining Company (which had been owned by MMC Norilsk Nickel in 2010). Palladium accounts for about 77 percent of the PGMs extracted from the complex, with the remainder being mostly platinum. The Stillwater mine opened in 1987 and, in 2010 , had a capacity of $12,100 \mathrm{~kg} / \mathrm{yr}$ of recoverable PGMs. The East Boulder mine opened in 2002 and, in 2010, had a production capacity of $5,600 \mathrm{~kg} / \mathrm{yr}$ of recoverable PGMs. The company conducts extensive exploration in an effort to maintain ore supplies and, since 1997, has been recovering an increasing amount of PGMs from spent catalytic converters at the Montana facility (MMC Norilsk Nickel, 2010a, p. 21). Small quantities of PGMs were also recovered as byproducts of copper refining operations in Texas and Utah.

PGMs are also present in the Duluth ultramafic complex in Minnesota. The most advanced project is the PolyMet Mining Inc.'s NorthMet copper-nickel project, which was undergoing an environmental impact statement review in 2010. Based on a 2006 feasibility study, the project could produce about $3,000 \mathrm{~kg} / \mathrm{yr}$ of refined PGMs, and first production was planned for 2017 (Polymet Mining Incorporated, 2009). Duluth Metals Limited was conducting early-stage exploration work at the Nokomis (Maturi Extension) copper-nickel-PGM project and the Birch Lake (Maturi) copper-nickel-PGM project; these projects were not expected to commence production before 2015 .

\section{Other Areas}

The Jinchuan nickel-copper mine in China has been operated by the Jinchuan Group Ltd. from the time it opened in 1963. In 2009, the mine had the capacity to produce up to $2,600 \mathrm{~kg} / \mathrm{yr}$ of recoverable PGMs. The operation was reportedly undergoing an expansion to increase nickel and copper production; a higher PGM capacity was not reported but would be likely (Jinchuan Group Ltd., 2010).

Yunnan Copper Corporation Ltd.'s Yunnan coppernickel-PGM mine in China was reported to have commenced 
production in 2010 , with an estimated capacity of $1,200 \mathrm{~kg} / \mathrm{yr}$ of recoverable PGMs.

Tati Nickel Mining Company (Pty.) Ltd. [a subsidiary of Norilsk Nickel Africa (Pty.) Ltd.] recovers PGMs from the Phoenix nickel-copper mine and affiliated facilities in Botswana. The mine commenced production in 1995 and, by 2010, was recovering up to 3,900 kg/yr of refined PGMs from copper-nickel matte (MMC Norilsk Nickel, 2010a, p. 55). Some of the matte is sent to the Harjavalta refinery in Finland for further processing. Ongoing processing modifications may reduce PGM recovery to $2,800 \mathrm{~kg} / \mathrm{yr}$ of recoverable PGMs.

Small quantities of PGMs are recovered as a byproduct of nickel and copper mining in Brazil. Nickel-copper matte is produced at the Fortaleza smelter from local mining operations, which is sent to the Harjavalta refinery in Finland for additional processing and PGM recovery.

Nickel-copper mines in Australia have historically produced an aggregated total of less than 1,000 kg of PGMs annually. Individual mines have a PGM capacity lower than the study cutoff, so were not included in this analysis. Although there are many base- or precious-metal projects in Australia that reportedly contain PGMs, the Panton PGMnickel-copper project is the most advanced of these projects. In 2008, a feasibility study evaluated the project using a design capacity of $1,500 \mathrm{~kg} / \mathrm{yr}$ of recoverable PGMs. Since 2008 , the project has been on hold, but the company was considering reviewing the viability of the project in light of increased PGM prices. It is unlikely that this project will be in production by 2015 .

\section{Estimates of Primary PGM Capacity}

After reviewing the data available for the PGM mines and projects presently producing, under development, and planned for development prior to 2015, estimates were developed for the historical and potential capacity for production of palladium and platinum from primary sources from 1995 through 2015. PGM capacity from secondary sources (recycled products containing PGMs) was not considered. Capacity estimates for the PGMs iridium, osmium, and ruthenium have been reported in tables $1-3$, but have not been analyzed separately because these PGMs would be recovered as byproducts from mines producing copper, nickel, palladium, or platinum. Estimates reflect the total refined capacity for each of the PGMs that could be recovered after mining and processing if the site were operating at design capacity. For vertically integrated operations, the PGM capacity of processing facilities associated with the site was considered when estimating site capacity. When mineral recovery is listed as less than 100 percent, capacity values are higher than production values.

Estimates of growth in global production capacity for platinum metal for operations considered in this analysis from 1995 through 2015 based on actual or anticipated capacity are shown in figure 4 . Similarly, figure 5 summarizes the estimated growth in global production capacity for palladium metal from 1995 through 2015. Global production capacity for platinum metal increased by about 57 percent to $268,000 \mathrm{~kg} / \mathrm{yr}$ of platinum in 2010 from

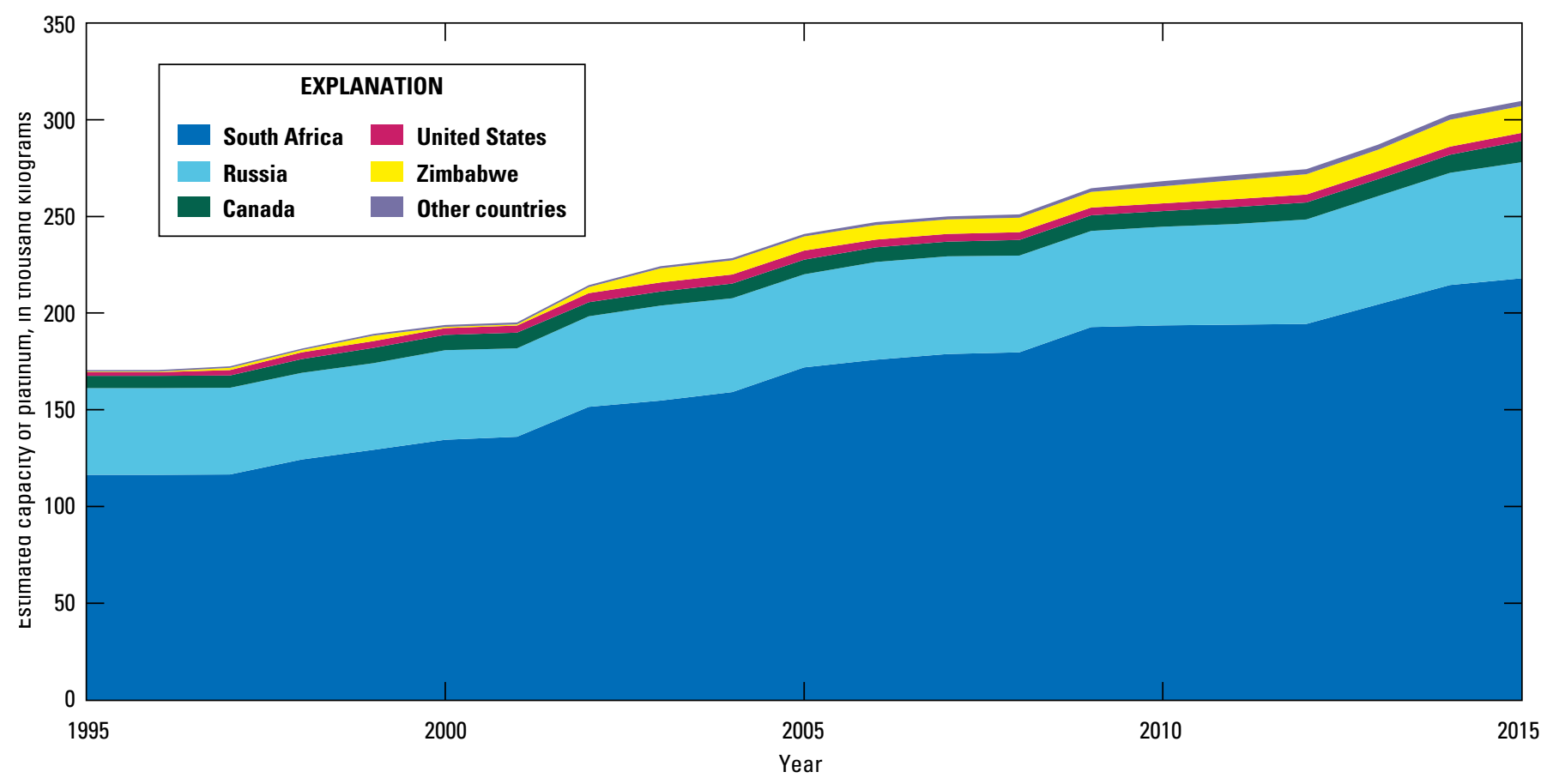

Figure 4. Estimated global production capacity for platinum from 1995 through 2015. Capacity is expressed in terms of potentially recoverable refined platinum metal. Data were compiled by the U.S. Geological Survey from available literature and oral communications. 


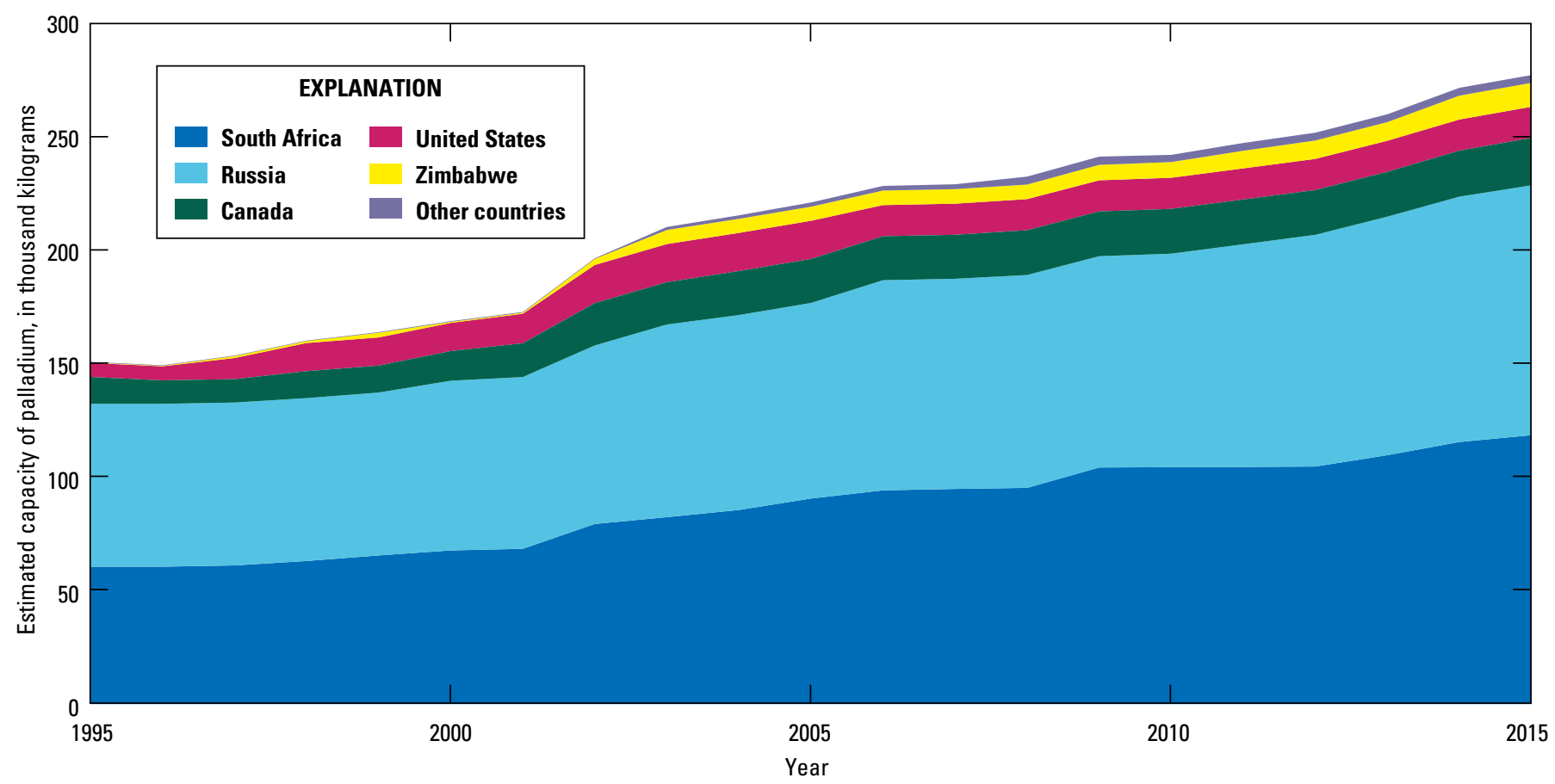

Figure 5. Estimated global production capacity for palladium from 1995 through 2015. Capacity is expressed in terms of potentially recoverable refined palladium metal. Data were compiled by the U.S. Geological Survey from available literature and oral communications.

about $171,000 \mathrm{~kg} / \mathrm{yr}$ of platinum in 1995. Between 2010 and 2015 , global production capacity for platinum metal was expected to increase by about 16 percent to $310,000 \mathrm{~kg} / \mathrm{yr}$ of platinum metal. Global production capacity for palladium metal increased by about 60 percent to $242,000 \mathrm{~kg} / \mathrm{yr}$ of palladium in 2010 from about $151,000 \mathrm{~kg} / \mathrm{yr}$ of palladium in 1995. Between 2010 and 2015, global production capacity for palladium metal was expected to increase by about 14 percent to $277,000 \mathrm{~kg} / \mathrm{yr}$ of palladium. The expected capacity increase is lower than the amount previously forecasted by industry primarily because of the global recession, which limited or curtailed the expansion and development plans of some projects.

The increase in production capacity for platinum from 1995 through 2010 was primarily a result of new or expanded capacity in South Africa $(77,000 \mathrm{~kg})$, Zimbabwe $(9,000 \mathrm{~kg})$, Russia (6,000 kg), Canada (2,000 kg), Botswana (2,000 kg), and the United States $(2,000 \mathrm{~kg})$. The increase in production capacity for platinum expected between 2010 and 2015 would primarily come from new or expanded capacity in South Africa $(24,000 \mathrm{~kg})$, Russia $(9,000 \mathrm{~kg})$, Canada $(3,000 \mathrm{~kg})$, and Zimbabwe (2,000 kg).

The increase in production capacity for palladium from 1995 through 2010 was primarily a result of new or expanded capacity in South Africa (44,000 kg), Russia (22,000 kg), Canada $(8,000 \mathrm{~kg})$, the United States $(8,000 \mathrm{~kg})$, Zimbabwe $(7,000 \mathrm{~kg})$, and Botswana $(3,000 \mathrm{~kg})$. The increase in production capacity for palladium expected between 2010 and 2015 would primarily come from new or expanded capacity in Russia $(16,000 \mathrm{~kg})$, South Africa $(14,000 \mathrm{~kg})$,
Zimbabwe (4,000 kg), and Canada $(1,000 \mathrm{~kg})$. It is likely that the magnitude of this increase in PGM capacity has been limited by such factors as the global economy, electrical capacity shortages in South Africa, mine safety concerns as a result of several recent mining accidents, and the legislative environment of South Africa.

Recycled PGMs have increasingly become important as a source of supply. In 2010, PGMs recovered from recycled automobile catalytic converters, electrical products, and jewelry accounted for about 31 percent of the gross global supply for rhodium, 30 percent of platinum, and 25 percent of palladium (Butler, 2011, p. 54-58). In 2010, about 34,000 kg of platinum, $41,000 \mathrm{~kg}$ of palladium, and 7,400 kg of rhodium were recycled from automobile catalytic converters, about $310 \mathrm{~kg}$ of platinum and $14,000 \mathrm{~kg}$ of palladium were recycled from electrical components, and about $23,000 \mathrm{~kg}$ of platinum and 2,600 kg of palladium were recycled from jewelry (Butler, 2011, p. 54-58). Since 2006, the amount of palladium and platinum recovered annually from recycled sources has increased at a higher rate than the increase in primary capacity for these metals.

During the past decade, demand for PGMs has increased with the increase in use of PGMs in automobile catalytic converters and electronic components. The growth of the fuel cell industry is expected to increase demand for PGMs during the next decade (TIAX LLC, 2003, p. 78). The amounts of mineral exploration and PGM recycling are also likely to increase during the next decade because PGM demand is expected to remain strong and existing sources of primary supply to become more expensive. 


\section{Factors Affecting PGM Capacity and Supply}

Many factors, including capital and operating costs, commodity prices, corporate finances, economic conditions, exchange and interest rates, government policies and taxes, and real and perceived risk factors, influence the timing and magnitude of the development of mineral supply. All these factors must be considered when evaluating the associations between existing operations, exploration activity, capacity expansion, and the development of new capacity. Several factors that have had a significant influence on PGM supply and the exploration and development of PGM properties during the study period have been reviewed in this analysis.

The links between demand, sources of supply, and market price for a mineral commodity are complex. Mineral exploration activity is generally heightened when there is the expectation that future demand for a mineral commodity will be higher than the anticipated supply. In the case of PGM supply derived from nickel and copper deposits, exploration is further influenced by the prices and supply and demand issues of the two metals. The amount of material substitution, recycling, and metal stocks must also be considered.

Because South Africa is the leading source of global production capacity for PGMs, an assessment of the events affecting the country's platinum capacity is worthwhile to understand some of the factors that affect PGM supply and demand. The growth in platinum capacity shown in figure 4 is related to the development and implementation of new mines to replace depleted resources and maintain existing capacity as well as the expansion of existing mines, concentrators, smelters, and refineries to provide additional PGM capacity. The mines considered in this analysis accounted for an average 97 percent of the platinum production and 99 percent of the palladium production reported by the USGS for South Africa from 1995 through 2010 (Reese, 1997; Hilliard, 1998-2011; George, 2006-2010; Loferski, 2011, 2012). The data suggest that, from 1995 through 2006, annual production capacity for primary platinum increased by about $77,000 \mathrm{~kg}$ (an average growth rate of about 4 percent per year) as a result of new mine capacity and expansion of existing mines and processing facilities. From 2006 through 2010, annual production capacity for platinum from primary sources increased by about $18,000 \mathrm{~kg}$ (an average growth rate of 2.5 percent per year). PGM capacity and supply for this same period, however, were affected by the global recession of 2008-09, which resulted in the temporary closure of several mines, development delays of planned operations, and production levels well below rated capacity. The growth of PGM capacity was also likely adversely affected by a number of South African issues that prevented operating mines from achieving production goals, including declining ore grades at some existing mines, processing difficulties at new mines, the shortage of electricity to process PGM ores and recover PGM products at concentrators and refineries, labor problems and safety issues, and excessive rainfall leading to flooding and temporary mine closures (South Africa Chamber of Mines, 2010).

Annual production capacity for platinum in South Africa from 2011 through 2015 was expected to increase by more than $24,000 \mathrm{~kg}$ (an average growth rate of 2.5 percent per year) as a result of the reopening of suspended mines and the development of new or expanded mining and processing operations where financing or construction had already been committed prior to the recession. It is possible that even more capacity would have been developed in South Africa had the economy remained strong. It is also possible that, should electrical power supply problems persist, any new development would favor shallow resources suitable for open pit mining, which requires less power than underground mining.

Analysis of exploration activity data and company development plans suggests that there have been no significant new PGM discoveries in areas that have not seen previous PGM production. Most of the increased primary PGM capacity took place in South Africa, Russia, Canada, and Zimbabwe, areas that have had PGM production for many years. Although exploration in Australia, Brazil, China, Finland, and the United States may lead to PGM production in the future, most of the global PGM capacity through 2020 will come from established areas. It is also unlikely that changes in mineral policy or social attitudes will affect the distribution of PGM capacity during the next decade. In 2020, the United States will likely continue to be highly dependent on PGMs from South Africa, Russia, Canada, and Zimbabwe. The United States, however, may reduce its dependency of foreign primary PGMs if the recycling rate for PGMs increases.

Exploration patterns at the larger, long-established PGM mining operations in Canada, Russia, and South Africa suggest that, even when exploration does not delineate large new deposits that would be suitable for expanding the capacity of the operation, exploration often better defines potential resources so the operation can develop a new ore zone to replace another ore zone that is being depleted, often with little change in site economics. The longevity of some global PGM mines is proof of this.

As new ore zones are identified, defined, and developed, facilities to process PGM-containing ores may need to be modified or expanded to accommodate new feed sources. Because processing is expensive, to maintain project viability, any additional processing costs must be offset by additional revenues generated by the deposit through higher grades or byproduct revenues. Likewise, as a greater amount of PGM capacity originates from deeper ore zones in South Africa, Canada, and the United States, the ore mined from these deposits will have to be of a higher grade to maintain the same rate of return on investment, or if mining or processing costs increase without a commensurate increase in the grade of the ore, then the price of the saleable products from that operation must also increase to maintain the desired rate of return.

In the long term, social and political conditions may also influence world mineral supply for an industry that is concentrated in a limited number of countries. Examples of 
policies and programs that have affected exploration, mining, and mineral development in South Africa since 1995 include the Mineral and Petroleum Resources Development Act of 2002 and the Black Economic Empowerment (BEE) program. The act changed the South African system of mineral rights from a dual state and private ownership system to exclusive state ownership with mining activities being licensed to private interests, and the BEE program required that black ownership of the mining industry reach 15 percent by 2009 and 26 percent by 2014 (Yager, 2010). In Zimbabwe, legislation was passed in 2008 which required that 51 percent of a business must be owned by native Zimbabweans; as of mid-2010, the implementation schedule of this legislation had not been decided (Mobbs, 2010).

PGM prices and the prices of other mineral commodities produced from deposits that recover byproduct PGMs often influence the level of mineral exploration and development. Figure 6 shows the average annual nominal prices of selected PGMs and associated base metals from 1995 through 2010. As a point of comparison, the 30-year (1980-2009) average price was $\$ 17,200$ per kilogram for platinum, $\$ 7,300$ per kilogram for palladium, $\$ 53,500$ per kilogram for rhodium, $\$ 2,200$ per metric ton for copper, and $\$ 8,100$ per ton for nickel. In general, PGM exploration activity was low from 1995 to 1998 (fig. 2), a period when nominal prices for platinum and palladium were lower than their average 30 -year price (fig. 6). PGM capacity increased by 33 percent from 1998 to 2005, a time when average nominal prices for palladium and platinum were higher than their average 30 -year price. From 2005 through 2010, PGM capacity increased by a further 17 percent, in spite of the economic recession of 2008-09. It is likely that higher prices for PGMs after 1998, nickel after 2002, and copper after 2004 were one factor that stimulated exploration and development of PGM deposits during much of the study period (fig. 6). Exploration activity data collected by the USGS suggest that global exploration activity for PGMs peaked during the 2002-03 period, perhaps partly in response to the 2000-01 peaks in PGM prices. The projected increase in PGM capacity after 2012 can partly be attributed to higher prices for PGMs and base metals from 2005 through 2007. The 6-year delay in new capacity is likely a result of the 200809 recession and the normal time lag between an expansion decision and the completion of new capacity construction.

\section{Summary and Conclusions}

Many factors determine whether or not a mineral deposit will be developed into a mine and the timing associated with development. The geologic depth and extentof the deposit, the grade of ore mineralization and related impurities, and the recoverability of the resource influence its economic viability. Once a resource has been adequately defined, a combination of external factors influences site development. Although the specific forces influencing the decision to develop each project

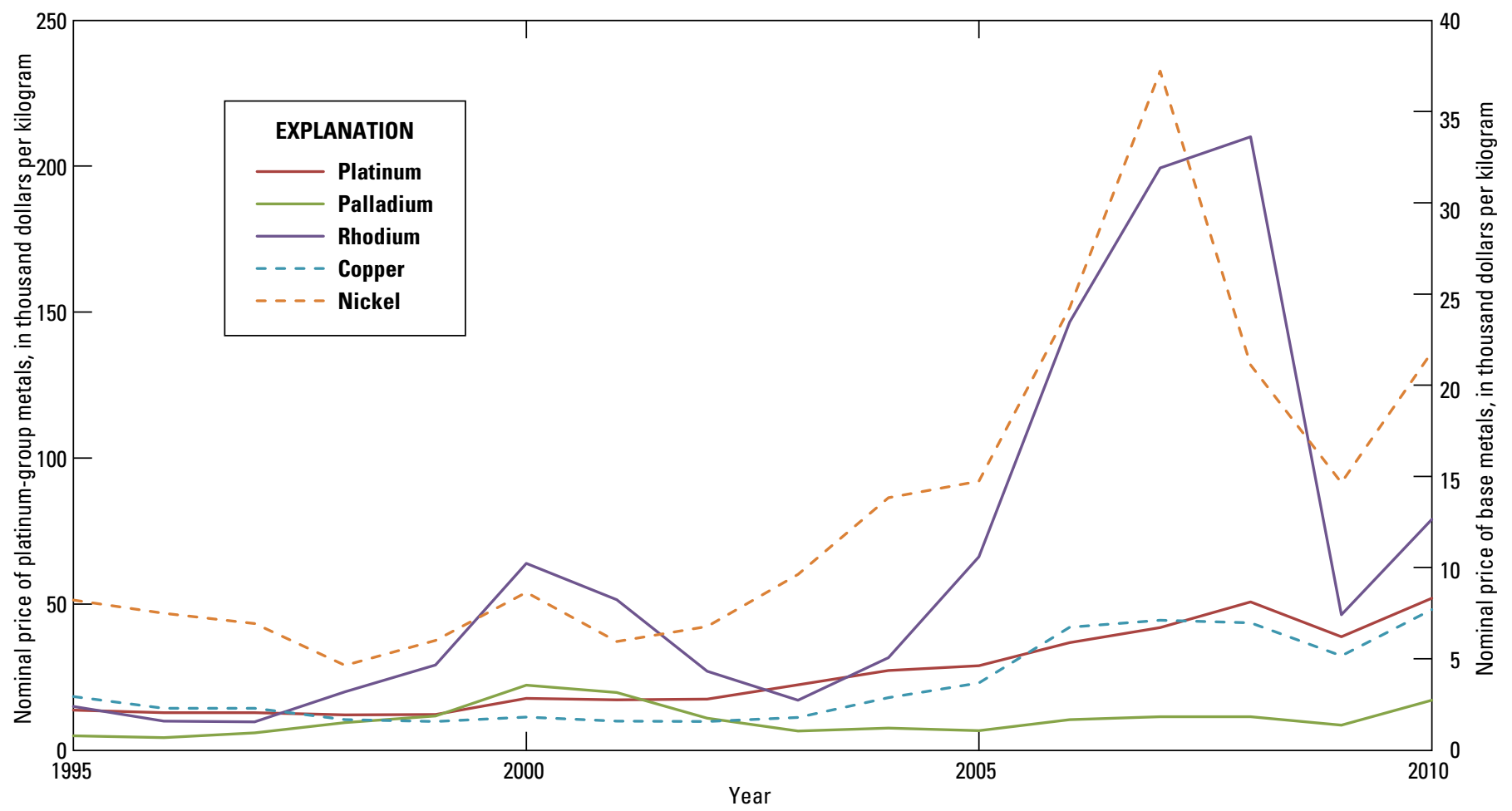

Figure 6. Average annual nominal prices of selected metals from 1995 through 2010. Data are from Reese (1997), Hilliard (1998-2011), George (2006-2010), and Loferski (2009-2011, 2011a,b). 
are often different, some general conclusions can be made based on ongoing U.S. Geological Survey global mineral activities.

The United States is highly dependent on foreign sources of platinum-group metals (PGMs) to meet increasing demand for these materials in a variety of applications. Principal sources of PGMs during the past 15 years have been South Africa, Russia, Canada, and Zimbabwe. These countries should continue to be the principal sources of PGMs at least for the next decade.

The production capacity of PGMs in South Africa increased from 1995 through 2006 as the industry responded to increased demand for PGMs by increasing mine exploration, which led to the development of replacement mines and new mines and the expansion of existing mine capacity. Capacity utilization decreased from 2006 through 2010 as a result of domestic energy shortages, labor and safety issues, and declining PGM demand as a result of the deterioration of the global economy. In spite of these short-term difficulties, the capacity to produce PGMs from South Africa from 2010 through 2015 was expected to increase to a level nearly double that of 1995 .

Global exploration for PGMs after 1995 focused primarily on maintaining or extending reserves of producing deposits, defining reserves of deposits adjacent to producing areas, and reassessing the PGM potential at base-metal deposits and mill tailings areas. Although exploration in other areas occurred, resources delineated by these activities were not sufficient to enable the development of significant PGM mines outside of historically producing areas during the study period. Mineral exploration enabled many mines to define and develop new zones to replace depleted ore zones so that PGM capacity could be maintained if not increased.

Sources of South African PGM supply are changing as the shallow Merensky deposits are being depleted, and deeper, higher cost Upper Group Reef seam 2 (UG2) deposits, which require modifications to the processing techniques, are being developed; a greater percentage of the supply of PGMs from South Africa is likely to come from the Eastern Bushveld deposits.

For mines that produced PGMs in South Africa in 1995, the Eastern Bushveld accounted for about 6 percent of the palladium reserve, 4 percent of the platinum reserve, and 4 percent of the rhodium reserve. It was estimated that the Eastern Bushveld would account for about 29 percent of the rhodium reserve, 27 percent of the palladium reserve, and 25 percent of the platinum reserve for mines producing PGMs in South Africa in 2015.

In general, ores from deposits in the Western Bushveld have a higher content of platinum but a lower content of palladium than deposits in the Eastern Bushveld. Although a typical PGM deposit in South Africa contains more platinum than palladium, as the amount of mining in the Eastern Bushveld increases, the proportional amount of palladium that is recoverable from South African deposits will likely increase. As the amount of mining from the UG2 seam deposits increases, the overall rhodium content of PGMs from South African deposits is likely to increase.
Although Russia will probably continue to be a significant supplier of PGMs from deposits on the Taimyr Peninsula and Kola Peninsula during the next decade, specific sources of supply for PGMs from Rissia are changing. The capacity of mines deriving PGMs from cuprous sulfides and sulfides with disseminated PGMs is increasing faster that the capacity of mines deriving PGMs from nickel-rich sulfide ores. The cuprous and disseminated ores generally have a lower PGM content and different palladium-to-platinum ratios than the nickel-rich ores that dominated PGM supply in the 1990s.

Because much of the PGM capacity from Canada and Russia is derived as a byproduct of copper and nickel mining, PGM capacity from these countries is influenced by economic, environmental, political, and technological factors affecting copper and nickel exploration and production in addition to factors influencing PGMs. Accurate resource delineation and mine scheduling allow producers to adjust mine production and processing to maximize material recovery and revenues with economic and market changes for these metals. The revenue generated by PGM production from a nickel and copper mine has increased as a percentage of the operation's total revenue.

Because PGM prices have increased since 2003, the recovery of PGMs from tailings derived from historical copper, nickel, and PGM mining operations has increased in Russia and South Africa.

The amount of PGMs being recycled has increased since 1995. Data suggest that recycled PGMs recovered from automotive, electrical, and jewelry applications accounted for about 30 percent of the world's supply of platinum and about 29 percent of the world's supply of palladium in 2010 . Since 2006, the amount of palladium and platinum recovered annually from recycled sources has increased at a faster rate than the that of the primary production capacity for these metals.

Global and local geopolitical conditions have influenced PGM supply and demand. Legislation regulating the structure of the mining sector has affected mining in Russia, South Africa, and Zimbabwe. Stricter vehicle emissions standards have led to mandatory use of pollution control devices, such as catalytic converters, containing PGMs in vehicles since the 1980s and could be required on vehicles in expanding markets, such as those in China and India. The global recession of 2008-09 decreased demand for PGMs and constrained PGM mine development. By the end of 2010, the consequences of the global recession continued to limit some exploration and development activities.

\section{References Cited}

African Rainbow Minerals Limited, 2010, ARM annual report 2009: African Rainbow Minerals Limited, 202 p., accessed September 20, 2010, at http://www.arm.co.za/im/files/ annual/2009/pdf/full.pdf. 
Anglo Platinum Limited, 2010, Overview and locations: Anglo Platinum Limited, accessed September 20, 2010, at http:// www.angloplatinum.com/business/operations/overview.asp.

Aquarius Platinum Limited, 2010, Operations at a glance: Aquarius Platinum Limited, accessed September 20, 2010, at http://www.aquariusplatinum.com/default. aspx?MenuID=19.

Butler, Jonathan, 2011, Platinum 2011: Royston, United Kingdom, Johnson Matthey plc, 60 p. at http://www.platinum.matthey.com/uploaded_files/PT_2011/ complete_publication.pdf.

Cawthorn, R.G., 1999, The platinum and palladium resources of the Bushveld Complex: South African Journal of Science, v. 95, November/December, p. 481-489. (Also available at http://www.platinum.matthey.com/uploaded files/ publications/Cawthorn.pdf, accessed September 20, 2010.)

Cowley, Alison, and Steel, Mike, 2001, Platinum 2001: Royston, United Kingdom, Johnson Matthey plc, 52 p. (Also available at http://www.platinum.matthey.com/ publications/pgm-market-reviews/archive/platinum-2001/.)

Eastern Platinum Limited, 2010, Corporate profile: Eastern Platinum Limited, accessed August 27, 2010, at http://www.eastplats.com/about_us/corporate_profile/.

European Commission, 2010, Critical raw materials for the EU: European Commission, July 30, 85 p., accessed January 25, 2012, at http://ec.europa.eu/enterprise/policies/ raw-materials/files/docs/report-b_en.pdf.

FNX Mining Company Inc., 2010, Annual information form for the year ended December 21, 2009: FNX Mining Company Inc., 40 p. accessed October 12, 2010, at http://www.quadrafnx.com/i/pdf/2009_AIF_Final_FNX.pdf.

George, M.W., 2006-2008, Platinum-group metals: U.S. Geological Survey Mineral Commodity Summaries 2006-2008, [variously paginated]. (Available at http://minerals.usgs.gov/minerals/pubs/commodity/ platinum/index.html.)

George, M.W., 2006-2010, Platinum-group metals, in Metals and minerals: U.S. Geological Survey Minerals Yearbook 2004-2008, v. I, [variously paginated]. (Available at http://minerals.usgs.gov/minerals/pubs/commodity/ platinum/index.html.)

Hilliard, H.E., 1998-2005, Platinum-group metals, in Metals and minerals: U.S. Geological Survey Minerals Yearbook 1996-2003, v. I, [variously paginated]. (Available at http://minerals.usgs.gov/minerals/pubs/commodity/ platinum/index.html.)

Hilliard, H.E., 1998-2005, Platinum-group metals: U.S. Geological Survey Mineral Commodity Summaries 1998-2005, [variously paginated]. (Available at http://minerals.usgs.gov/minerals/pubs/commodity/ platinum/index.html.)
Impala Platinum Holdings Limited, 2010, Our business: Impala Platinum Holdings Limited, accessed September 20, 2010, at http://www.implats.co.za/b/b_i.asp.

Jinchuan Group Ltd., 2010, Development prospect: Jinchuan Group Ltd., accessed September 2, 2010, at http://www.jnmc.com/en_about/prospect.htm.

Johnson Matthey plc, 2010, South Africa: Johnson Matthey plc, accessed October 18, 2010, at http://www.platinum.matthey.com/production/south-africa/.

Kendall, Tom, 2003, Platinum 2003: Royston, United Kingdom, Johnson Matthey plc, 52 p. (Also available at http://www.platinum.matthey.com/publications/pgmmarket-reviews/archive/platinum-2003/.)

Kendall, Tom, 2004, Platinum 2004: Royston, United Kingdom, Johnson Matthey plc, 56 p. (Also available at http://www.platinum.matthey.com/publications/pgmmarket-reviews/archive/platinum-2004/.)

Levine, R.M., Brininstool, Mark, and Wallace, G.J., 2010, The mineral industry of Russia, in Area reports-InternationalEurope and Central Eurasia: U.S. Geological Survey Minerals Yearbook 2007, v. III, p. 35.1-35.26. (Also available at http://minerals.er.usgs.gov/minerals/pubs/ country/2007/myb3-2007-rs.pdf.)

Levine, Richard, and Wilburn, David, 2003, Russian PGM-Resources for $100+$ years: U.S. Geological Survey Open-File Report 2003-059, 19 p., available at http://pubs.usgs.gov/of/2003/of03-059/index.html.

Loferski, P.J., 2009-2011, Platinum-group metals: U.S. Geological Survey Mineral Commodity Summaries 2009-2011, p. 120-121. (Also available at $\mathrm{http}: / /$ minerals.er.usgs.gov/minerals/pubs/commodity/ platinum/mcs-2010-plati.pdf.)

Loferski, P.L., 2011, Platinum-group metals in March 2011: U.S. Geological Survey Mineral Industry Surveys, 6 p.

Loferski, P.J., 2012, Platinum-group metals, in Metals and minerals: U.S. Geological Survey Minerals Yearbook 2010, v. I, p. 57.1-57.12. (Also available at http://minerals.usgs.gov/minerals/pubs/commodity/ platinum/myb1-2010-plati.pdf.)

Lonmin plc., 2010, Our business: Lonmin, plc., accessed September 20, 2010, at http://www.lonmin.com/ business.aspx?pageid $=9$.

Magma Metals Limited, 2011, Positive scoping study for Thunder Bay North project: Magma Metals Limited, 9 p., accessed February 7, 2011, at http://www.connect4.com.au/ fcas/casdeliver.cgi?img $=01148523$.

McConnachie, T.M., 2010, Leading low-risk dump and near surface PGE producer: Sylvania Resources Limited, accessed February 20, 2012, at http://www.sylvaniaplatinum.com/im/ files/documents/071010_SLV_October_Presentation_ASX_ Amended.pdf. 
McMahon, Fred, and Cervantes, Miguel, 2010, Survey of mining companies 2009/2010, 2010 mid-year update: Fraser Mining Institute, 64 p., accessed September 21, 2010, at http://www. fraserinstitute.org/uploadedFiles/fraser-ca/Content/researchnews/research/publications/miningsurvey-2010update.pdf.

Metals Economics Group, 2010, World platinum supply pipeline: Metals Economics Group Strategic Report, v. 23, no. 3 , p. 3 .

MMC Norilsk Nickel, 2010a, Annual report MMC Norilsk Nickel 2009, 255 p., accessed October 23, 2010, at http://www.nornik.ru/_upload/year2009/GO_NN_2009_ Eng_site.pdf.

MMC Norilsk Nickel, 2010b, The investor day held by MMC Norilsk Nickel in London: MMC Norilsk Nickel press release, May 18, accessed September 21, 2010, at http://www.nornik.ru/en/press/news/2940/.

MMC Norilsk Nickel, 2010c, Our products: MMC Norilsk Nickel, accessed September 21, 2010, at http://www.nornik.ru/en/our_products/.

Mobbs, P.M., 2010, The mineral industry of Zimbabwe, in Area reports-International-Africa and the Middle East: U.S. Geological Survey Minerals Yearbook 2008, v. III, p. 43.1-43.6. (Also available at http://minerals.er.usgs.gov/ minerals/pubs/country/2008/myb3-2008-zi.pdf.)

Murahwi, Charley, Shoemaker, Sam, Gowans, Richard, Lemieux, John, and Jacobs, Christopher, 2010, Technical report on the updated feasibility study for the Marathon PGM-Cu project, Marathon, Ontario, Canada: Marathon PGM Corporation, January 8, 212 p., accessed March 14, 2012, at http://www. marathonpgmproject.com/database/asp/ReportUploads/6.pdf.

National Research Council, 2008, Minerals, critical minerals, and the U.S. economy: Washington, DC, National Academies Press, 264 p. (Also available at http://books.nap.edu/openbook.php?record $\mathrm{id}=12034$ \&page $=165$.)

North American Palladium Ltd., 2010, North American Palladium releases positive scoping study on the Offset zone: Toronto, Canada, North American Palladium Ltd. press release, August 16, 8 p., accessed September 21, 2010, at http://cnrp. marketwire.com/cnrp_files/20100816-pdl816b.pdf.

Northam Platinum Limited, 2010, About us: Northam Platinum Limited, accessed September 20, 2010, at http://www.northam.co.za/about/about_intro.asp.

Platinum Australia Limited, 2010, Annual report 2010: Platinum Australia Limited, xxx p., accessed September 20, 2010, at http://www.platinumaus.com.au/inews_files/ Annual\%20Report\%202010\%20jdl\%20_2_.pdf.

Platmin Limited, 2010, Our assets: Platmin Limited, accessed September 20, 2010, at http://www.platmin.com/p/p_i.asp.
Polymet Mining Incorporated, 2009, Northmet projectDraft environmental impact statement: Poly,et Mining Incorporated, October, 714 p., accessed March 14, 2012, at http://files.dnr.state.mn.us/input/environmentalreview/ polymet/draft_eis/volume_i_text_and_tables_deis.pdf.

Reese, R.G., Jr., 1996-1997, Platinum-group metals: U.S. Geological Survey Mineral Commodity Summaries 1996-1997, [variously paginated]. (Available at http://minerals.usgs.gov/minerals/pubs/commodity/ platinum/index.html.)

Reese, R.G., Jr., 1997, Platinum-group metals, in Metals and minerals: U.S. Geological Survey Minerals Yearbook 1995, v. I, 4 p. (Available at http://minerals.usgs.gov/minerals/ pubs/commodity/platinum/index.html.)

Smit, Petronel, 2010, Two Rivers plant improvement on track: Creamer Media's Mining Weekly, v. 16, no. 2, p. 60. (Also available at http://www.miningweekly.com/article/tworivers-plant-improvement-on-track-2009-12-04.)

South Africa Chamber of Mines, 2010, Annual report 2008-2009: South Africa Chamber of Mines, 109 p., accessed October 15, 2010, at http://www.bullion.org.za/ Publications/Annual2009/AR 2009.pdf.

TIAX LLC, 2003, Platinum availability and economics for PEMFC commercialization: U.S. Department of Energy report DE-FC04-01AL67601, December, 100 p. (Also available at http://www1.eere.energy.gov/ hydrogenandfuelcells/pdfs/tiax_platinum.pdf.)

Vermaak, C.F., 1995, The platinum-group metals-A global perspective: Randberg, South Africa, Mintek, $247 \mathrm{p}$.

Wesizwe Platinum Limited, 2010, Forward looking \& ... focusing on the future: Wesizwe Platinum Limited strategic overview presentation, 49 p., accessed September 20, 2010, at http://www.wesizwe.co.za/downloads/presentations/ Microsoft $\% 20$ PowerPoint $\% 20-\% 20$ Roadshow $\% 20$ 20100602.1.pdf.

Wilburn, D.R., and Bleiwas, D.I., 2005, Platinum-group metals-World supply and demand: U.S. Geological Survey Open-File Report 2004-1224, 130 p., accessed September 20, 2010, at http://pubs.usgs.gov/of/2004/1224/index.html.

Xstrata plc, 2010, Annual report 2009: Zug, Switzerland, Xstrata plc, 228 p. (Also available at http://www.xstrata. com/annualreport/2009/servicepages/welcome.html.)

Xstrata plc, 2011, Half-yearly report 2011: Zug, Switzerland, Xstrata plc, 84 p. (Also available at http://www.xstrata.com/ content/assets/pdf/xta-ir2011_en.pdf.)

Yager, T.R., 2010, The mineral industry of South Africa, in Area reports-International-Africa and the Middle East: U.S. Geological Survey Minerals Yearbook 2008, v. III, p. 37.1-35.22. (Also available at http://minerals.er.usgs.gov/ minerals/pubs/country/2008/myb3-2008-sf.pdf.) 
Prepared by the Pembroke and Reston Publishing Service Centers.

For more information concerning this report, contact: Director

U.S. Geological Survey

National Minerals Information Center

12201 Sunrise Valley Drive

Reston, VA 20192

nmicrecordsmgt@usgs.gov

or visit our Web site at

http://minerals.usgs.gov/minerals/. 
